\title{
New information on Riograndia guaibensis Bonaparte, Ferigolo \& Ribeiro, 2001 (Eucynodontia, Tritheledontidae) from the Late Triassic of southern Brazil: anatomical and biostratigraphic implications
}

\author{
MARINA B. SOARES, CESAR L. SCHULTZ and BRUNO L.D. HORN \\ Departamento de Paleontologia e Estratigrafia, Instituto de Geociências, Universidade Federal do Rio Grande do Sul \\ Av. Bento Gonçalves, 9500, Caixa Postal 15.001, 91501-970 Porto Alegre, RS, Brasil \\ Manuscript received on December 20, 2010; accepted for publication on January 24, 2011
}

\begin{abstract}
The tritheledontid Riograndia guaibensis was the first cynodont described for the "Caturrita Formation" fauna from the Late Triassic of southern Brazil (Santa Maria 2 Sequence). The type materials did not preserve anatomical information regarding braincase, occiput, basicranium, zygomatic arch, postdentary bones and craniomandibular joint. Here new materials are described and supply the missing information. Riograndia shows a suite of important anatomical features quite derived among the non-mammaliaform eucynodonts, such as the partial closure of the medial orbital wall and braincase, extensive secondary osseous palate, wide primary palate, basicranium with jugular foramen separated from the periphery of fenestra rotunda, narrow zygomatic arch and much reduced postdentary bones. Many of these features constitute synapomorphies shared only with the other members of mammaliamorpha. Thus, the almost complete cranial, mandibular and dental information from the new fossils of Riograndia can bring a significant improve in the understanding of the anatomy and phylogenetic relationships of the tritheledontids and help to elucidate the transformational steps involved in the cynodont-mammal transition. Additionally, Riograndia is a key taxon in refining the "Caturrita Formation" biostratigraphy, enabling the connection of several fossiliferous outcrops that have a rich tetrapod fauna that can be correlated with other Triassic faunas from Gondwana and Laurasia.
\end{abstract}

Key words: Caturrita Formation, Cynodontia, Late Triassic, Riograndia, Tritheledontidae.

\section{INTRODUCTION}

The upper Triassic beds of southern Brazil assigned as "Caturrita Formation" (e.g. Andreis et al. 1980) or the "upper portion of the Santa Maria 2 Sequence" (Zerfass et al. 2003) became renowed for their primitive dinosaur containning, represented by the prosauropod $U n$ aysaurus tolentinoi Leal, Azevedo, Kellner \& Da Rosa, 2003, and the theropod (sensu Langer et al. 2009) Guaibasaurus candelariensis Bonaparte, Ferigolo \& Ribeiro, 1999. Other than these dinosaurs, these beds also produce the dinosauriform Sacisaurus agudoensis Ferigolo \& Langer, 2006, the dicynodont Jachaleria candelar-

Proceedings of the Third Gondwanan Dinosaur Symposium Correspondence to: Marina Bento Soares

E-mail: marina.soares@ufrgs.br iensis Araújo \& Gonzaga, 1980, an indeterminate phytosaur (Lucas and Kischlat 2003), isolated teeth of archosaurs (Dornelles 1990) and a stereospondyl amphibian (Dias-da-Silva et al. 2009). However, the most surprising findings from these layers are related with a new and extremely rich association of small tetrapods, which are less than $15 \mathrm{~cm}$ length. This fauna has yielded the procolophonid Soturnia caliodon Cisneros \& Schultz, 2003, the sphenodontid Clevosaurus brasiliensis Bonaparte \& Sues, 2006, the lepidosaur Cargninia enigmatica Bonaparte, Schultz, Soares \& Martinelli, 2010, the pterosaur Faxinalipterus minima Bonaparte, Schultz, Soares \& Martinelli, 2010, and five taxa of advanced non-mammaliaform cynodonts (sensu Abdala 2007). 
Among these, Riograndia guaibensis Bonaparte, Ferigolo \& Ribeiro, 2001 was the first one reported, followed by Brasilodon quadrangularis, Brasilitherium riograndensis Bonaparte, Martinelli, Schultz \& $\mathrm{Ru}-$ bert, 2003, Irajatherium hernandezi Martinelli, Bonaparte, Schultz \& Rubert, 2005, and Minicynodon maieri Bonaparte, Schultz, Soares \& Martinelli, 2010. We judge important to emphasize here that, unlike Liu and Olsen (2010), we follow the view of Bonaparte et al. (2003, 2005, 2010) who consider Brasilodon and Brasilitherium different from each other and, therefore, as valid taxa. This whole fauna indicates a Norian age for the layers where it occurs (see Geological Setting and Biostratigraphy section).

Previous knowledge about Riograndia guaibensis is based on the description of the holotype MCN-PV2264 , represented by an incomplete skull with dentition, and its related materials, which consist of a left mandible with dentition, but lacking post dentary bones (MCN-PV2265), and a fragmented right mandible with three postcanines teeth (MCN-PV2271) (Bonaparte et al. 2001) (Fig. 1). Bonaparte et al. (2001) recognized several synapomorphies shared by Riograndia and the "ictidosaurs" (or Tritheledontidae sensu Hopson and Kitching 1972), but proposed the monotypic family Riograndidae to include the only species Riograndia guaibensis.

The type series of Riograndia (Bonaparte et al. 2001) did not provide anatomical information on the orbital wall, braincase, basicranium, primary palate, occiput, zygomatic arch, postdentary bones and craniomandibular joint. Fortunately, new and more complete materials of Riograndia were collected, supplying the missing information concerning these anatomical regions. The new materials include four well-preserved skulls with teeth and several mandibular specimens with teeth, two of them with the postdentary bones preserved. It is noteworthy that although many postcranial elements have been found in field works, none of them can be confidently assigned to Riograndia. These new cranial, mandibular and dental materials show important derived features, many of them suggesting a closer affinity among Riograndia, Pachygenelus (and other tritheledontids) and Mammaliaformes (sensu Rowe 1988, Kielan-Jaworowska et al. 2004, Luo 2007).
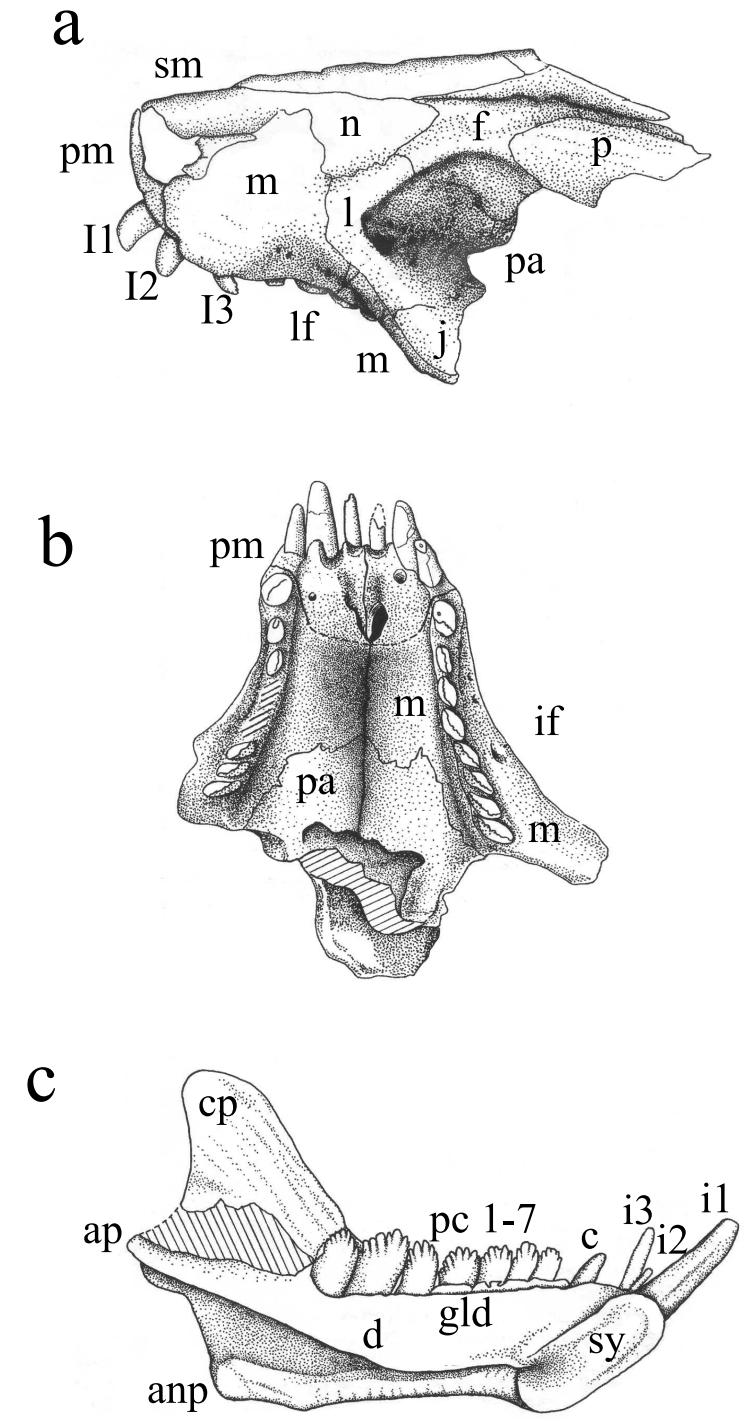

Fig. 1 - Riograndia guaibensis MCN-PV2264, holotype. (a) dorsolateral view; (b) ventral view; (c) MNCP-PV2265, medial view of the left mandible with dentition. Scale bar: $10 \mathrm{~mm}$. anp, angular process; ap, articular process; cp, coronoid process; d, dentary; f, frontal; gld, groove for dental lamina; if, infraorbital foramen; i1, lower incisor $1 ; \mathrm{j}$, jugal; 1, lacrimal; lf, lacrimal foramina; m, maxilla; mc, Meckel canal; n, nasal; p, parietal; pa, palatine; pm, premaxilla; sm, septomaxilla; sy, symphysis. Modified from Bonaparte et al. (2001).

Although considered by many authors (Hopson and Barghusen 1986, Hopson 1991, Crompton and Luo 1993, Luo 1994, Hopson and Kitching 2001, Luo et al. 2002, Kielan-Jaworowska et al. 2004) as being the sister group of mammals, the "Ictidosaurs" or Tritheledontidae are normally represented by poorly preserved 
and incomplete specimens. Thus, the cranial, mandibular and dental information from the new specimens of Riograndia should greatly improve our understanding of the anatomy of the Tritheledontidae, should help to elucidate the intermediate transformational steps in the cynodont-mammal transition, and provides new data to unravel the interrelationships within Cynodontia.

Martinelli et al. (2005) showed Riograndia to be the most basal taxon within Tritheledontidae (Fig. 2a), while Martinelli and Rougier (2007) placed Riograndia as the most basal taxon of the monophyletic Ictidosauria Clade, and as sister taxon of the most inclusive Tritheledontidae, composed by Irajatherium, Chaliminia, Elliotherium, Pachygenelus, Diarthrognathus, and Tritheledon (Fig. 2b). Recently, Liu and Olsen (2010) used, among the tritheledontids, only Riograndia and Pachygenelus in their analysis and did not recognize Tritheledonta as a monophyletic group (Fig. 2c). Nevertheless, the authors support the close relationship between Riograndia and Pachygenelus. They emphasize that the possibility of a monophyletic Ictidosauria (sensu Martinelli and Rougier 2007) group cannot be excluded and needs additional tests. In any case, Riograndia is closely related to other tritheledontids (or tritheledontians) than other non-mammaliaform cynodonts; the new materials presented here reinforce this phylogenetic hypothesis. In this paper we adopted the view of Martinelli et al. (2005), who place Riograndia as the most basal Tritheledontidae.

Riograndia also plays an important role in the enlightenment of the biostratigraphic context of the Upper Triassic sequence from southern Brazil, because this non-mammaliaform cynodont is commonly represented in the faunal association of the "Caturrita Formation", both in number of individuals and in wide geographic distribution.

\section{INSTITUTIONAL ABBREVIATIONS}

MCN - Museu de Ciências Naturais, Fundação Zoobotânica do Rio Grande do Sul (FZBRS), Rio Grande do Sul, Brazil.

UFRGS-PV-T - Universidade Federal do Rio Grande do Sul, Rio Grande do Sul, Brazil.

UNISINOS - Universidade do Vale do Rio dos Sinos, Rio Grande do Sul, Brazil.

\section{SYSTEMATIC PALAEONTOLOGY}

THERAPSIDA Broom, 1905

Cynodontia Owen, 1861

EUCYNODONTIA Kemp, 1982

Probainognathia Hopson, 1990

TRITHELEDONTIDAE Broom, 1912

Riograndia Bonaparte, Ferigolo \& Ribeiro, 2001

Riograndia guaibensis

Bonaparte, Ferigolo \& Ribeiro, 2001

Holotype: MCN-PV2264, anterior portion of the skull, from the tip of snout to the fronto-parietal contact, with complete dentition.

Hipodigm: MCN-PV2265, an almost complete lower jaw with complete dentition lacking the postdentary bones and MCN-PV2271, fragment of the middle portion of right lower jaw, with three postcanines.

Referred specimens: UFRGS-PV-0569-T, almost complete skull lacking zygomatic arches occluding with the lower jaws and teeth; UFRGS-PV-0601-T, almost complete skull lacking zygomatich arches, with incomplete dentition; UFRGS-PV-0833-T, skull in palatal view with teeth and a left mandibular ramus with postdentary bones; UFRGS-PV-0622-T, left dentary with teeth in lingual view; UFRGS-PV-0623-T, right mandibular ramus with teeth, preserved in buccal view; UFRGS-PV-0624$\mathrm{T}$, right mandibular ramus with part of the postdentary bones and teeth; UNISINOS-4881, anterior portion of skull with teeth; UFRGS-PV-0788-T, fragment of a left maxilla with the canine and seven postcanines; UFRGSPV-01062-T, isolated canine tooth; UFRGS-PV-01062$\mathrm{T}$, isolated incisor tooth; UFRGS-PV-0842-T and MCNPV10204, isolated postcanine teeth.

Locality and horizon: The specimens MCN-PV2264, MCN-PV2265, MCN-PV2271, UFRGS-PV-0596-T and UFRGS-PV-0601-T are from Sesmaria do Pinhal 1 outcrop (Candelária municipality); UFRGS-PV-0624T, UFRGS-PV-0833-T, UFRGS-PV-0842-T and UNISINOS-4881 are from Linha São Luiz outcrop (Faxinal do Soturno municipality). The specimens UFRGSPV-01062-T and MCN-PV10204 are from Botucaraí outcrop (Candelária municipality) and Sacisaurus Site (Agudo municipality), respectively. These outcrops are located approximately $200 \mathrm{~km}$ west from Porto Alegre, 

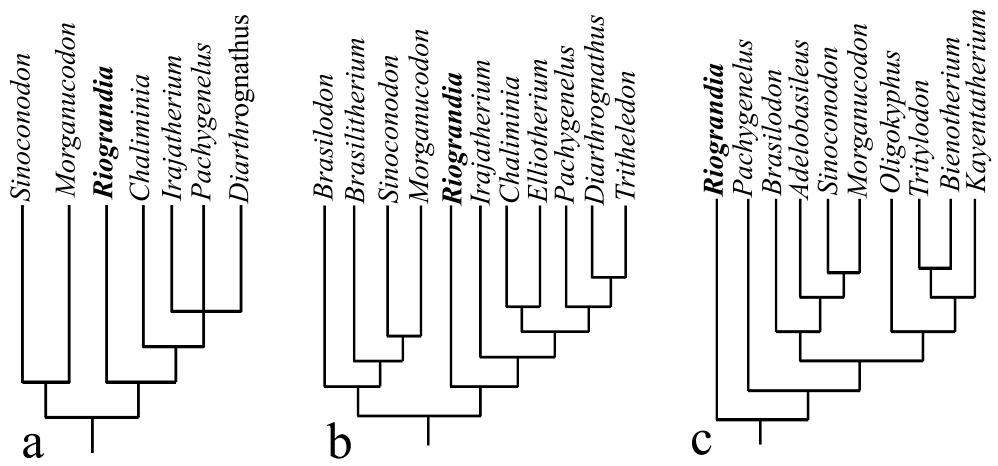

Fig. 2 - Partial cladograms for Eucynodontia showing the relationships between Riograndia and the other Mammaliamorpha (sensu Kielan-Jaworowska et al. 2004, Luo 2007). (a) adapted from Martinelli et al. (2005); (b) adapted from Martinelli and Rougier (2007); (c) adapted from Liu and Olsen (2010).

capital of Rio Grande do Sul State, Brazil. "Caturrita Formation" (Santa Maria 2 Sequence), Norian age (see Geological Setting and Biostratigraphy).

Emended diagnosis: small tritheledontid (sensu Martinelli et al. 2005) with the combination of the following derived characters: three upper and three lower incisors; reduced upper incisor 1 and hypertrophied lower incisor 1; upper canines larger than the lower ones; postcanines blade-like with 5-9 small, sharp and subequal cuspules evenly distributed on the almost semicircular border of the crown in the upper postcanine crown and in the posterodorsal border of the lower ones; postcanine teeth forming an angle with the long axis of the palate; elongated septomaxilla bordering the posterior margin of the external nares; frontal with an anterolateral projection contacting the nasal medially; absence of prefrontal; postorbital bar absent; dorsoventrally deep lacrimal; contact of the ventral process of frontal with the ascending process of palatine; sphenopalatine foramen bordered by the ascending process of palatine; ossified orbitosphenoid; weak anterior portion of the zygomatic arch; dorsoventrally narrow zygomatic arch; wider amplitude of the zygomatic arch at the half of the arch; quadrate suspended by the squamosal; premaxilla bordering the posterior margin of the incisive foramen; maxilla participating of the anterior margin of the subtemporal fossae in palatal view; maxilla excluded from the ventral margin of the subtemporal fossa by the jugal in lateral view; secondary osseous palate extending posteriorly to the last postcanine; presence of the lesser pala- tine foramina in the secondary osseous palate; wide primary palate; intermediate pterygopalatine ridges reaching the basisphenoid; broad interpterygoid vacuities; basisphenoid wing excluded from the margin of the fenestra ovalis; jugular foramen separated from the fenestra rotunda; two hypoglossal foramina outside the margin of the jugular foramen; prootic and opisthotic unfused; ascending process of the alisphenoid moderately expanded; open pterygoparoccipital foramen; postdentary bones reduced in a rod-like bar; dentary symphysis unfused; the articular process of the dentary in contact with the squamosal.

\section{GEOLOGICAL SETTING AND BIOSTRATIGRAPHY}

Several specimens of Riograndia were collected from four outcrops (Fig. 3) of Rio Grande do Sul State, southern Brazil, making possible to attempt the temporal correlation among them.

This taxon occurs predominantly in the Linha São Luiz outcrop (29 $\left.33^{\prime} 29^{\prime \prime} \mathrm{S} ; 53^{\circ} 26^{\prime} 55^{\prime \prime} \mathrm{W}\right)$, located near Faxinal do Soturno city and in Sesmaria do Pinhal 1 outcrop $\left(29^{\circ} 41^{\prime} 08.5^{\prime \prime} \mathrm{S} ; 52^{\circ} 50^{\prime} 45^{\prime \prime} \mathrm{W}\right)$, near Candelária city. An isolated first lower incisor (UFRGS-PV-01062$\mathrm{T})$, diagnostic of Riograndia, was found in the Botucaraí outcrop ( $\left.29^{\circ} 40^{\prime} 53^{\prime \prime} \mathrm{S} ; 52^{\circ} 50^{\prime} 28^{\prime \prime} \mathrm{W}\right)$, also located near Candelária city, and another postcanine tooth $(\mathrm{MCN}-$ PV10204) was collected in the Sacisaurus site, in Agudo city $\left(19^{\circ} 43^{\prime} 12^{\prime \prime} \mathrm{S} ; 47^{\circ} 45^{\prime} 04^{\prime \prime} \mathrm{W}\right)$.

All these fossiliferous outcrops were formerly included in the so-called "Caturrita Member" of the Botucatu Formation (sensu Bortoluzzi 1974) or in the "Catur- 


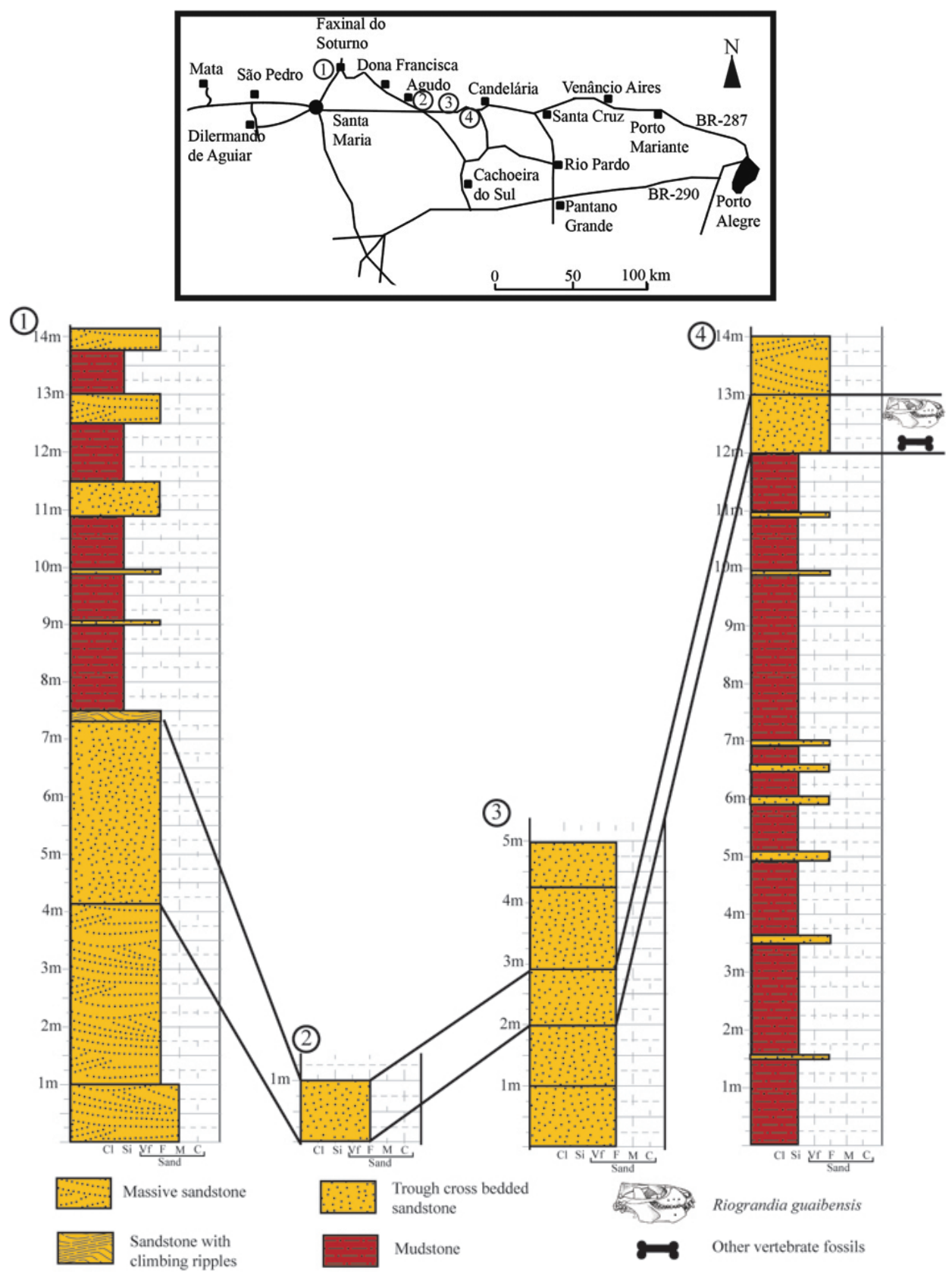

Fig. 3 - Location map and stratigraphic correlation of the four fossiliferous outcrops where Riograndia guaibensis occurs.

rita Formation" (sensu Andreis et al. 1980) (Fig. 4). In 1989, U.F. Faccini (unpublished data) firstly studied the Triassic sedimentary sequence of southern Brazil by using the sequence stratigraphy and demonstrated that the "Caturrita Formation" (sensu Andreis et al. 1980) had two distinct depositional sequences (both Triassic) that he called Sequence II and Sequence III (Faccini et al. 1995). The fossils here discussed came from the upper layers of the Sequence II.
Zerfass et al. (2003) refin this allostratigraphic framework, establishing two second-order supersequences for the south Brazilian Triassic (Fig. 4). The upper one, named Santa Maria Supersequence (MiddleLate Triassic) was divided into three third-order sequences, numbered from 1 to 3 , which correspond to the Sequence II of U.F. Faccini (unpublished data). The Santa Maria 2 Sequence (sensu Zerfass et al. 2003) consists of a coarsening-upward succession that begins 
with red mudstones interbedded with small-scale trough cross-bedded sandstone lenses. Rhytmites and sigmoidal massive to climbing cross-laminated sandstone bodies are also present. This facies association is interpreted as a lacustrine-deltaic depositional system. This basal portion of the Santa Maria 2 Sequence encompasses the Hyperodapedon Assemblage Zone (sensu Abdala et al. 2001), in which the most abundant components are the rhynchosaur Hyperodapedon and the traversodontid cynodont Exaeretodon. They permit to correlate these levels with those of the Ischigualasto Formation from Argentina, whose basal layer was dated as 230.3-231.4 $\pm 0.3 \mathrm{My}$ (Rogers et al. 1993, Furin et al. 2006, Martinez et al. 2011).

Upwards, the sandstone content of the Santa Maria 2 Sequence increases. The arenous layers occur as narrow, massive or stratified (horizontal and trough cross bedding) lenses interpreted as amalgamated sandstone bodies related to high width/depth ratio channels. This succession is interpreted as the progressive replacement of a lacustrine basin by a fluvial system.

H. Zerfass (personal communication) does not exclude the hypothesis that the upper layers of the Santa Maria 2 Sequence could in fact constitute another depositional sequence, but more detailed stratigraphic work in the area is needed to test this hypothesis, once the currently available evidences do not suggest any significant depositional gap inside this package. Nowadays, seven fossiliferous outcrops are assigned to the upper portion of the Santa Maria 2 Sequence in the Rio Grande do Sul State, as shown in the Table I.

The individualization of a biostratigraphic unit for the upper portion of the Santa Maria 2 Sequence was first proposed by C.M.S. Scherer (unpublished data) who have recognized that the Botucaraí outcrop, from which were recovered the dicynodont Jachaleria candelariensis and isolated archosaur's teeth, had distinct sedimentary faces and represented a younger horizon than the Rhynchosauria Cenozone (= Hyperodapedon AZ) (Schultz et al. 2000). In such a stratigraphic framework, the Botucaraí outcrop should be correlated with the basal layers of the Los Colorados Formation of Argentina, where Jachaleria colorata Bonaparte, 1970 was recorded and that overlaps the Ischigualasto Formation (marked by the presence of hyperodapedontidae rhyn- chosaurs). This correlation indicated (at that time) a Norian age for the Botucaraí fauna and allowed the recognition of an informal biostratigraphic unit to the Brazilian beds containing that dicynodont genus, named " $J a$ chaleria Interval" (C.M.S. Scherer unpublished data). Some years later, other outcrops were found near the Botucaraí Outcrop, and in Agudo and Faxinal do Soturno cities (ca. $100 \mathrm{~km}$ west from the Botucaraí region). These outcrops correspond to the upper levels of the Santa Maria 2 Sequence (sensu Zerfass et al. 2003), and have produced the dinosaur Guaibasaurus candelariensis (Bonaparte et al. 1999, 2006) and small vertebrates. Based on these new discoveries, especially on the abundant materials of the "ictidosaur" Riograndia (Bonaparte et al. 2001), Rubert and Schultz (2004) proposed a formal biostratigraphic name - Ictidosauria Assemblage Zone - to replace the "Jachaleria Interval". Further, this denomination was changed to Mammaliamorpha Assemblage Zone by Schultz and Soares (2006) based on the argument that this last name better reflects the phylogenetic status of the small non-mammaliaform cynodonts (e.g. Riograndia, Irajatherium, Brasilodon, Brasilitherium) of the upper levels of the Santa Maria 2 Sequence.

Langer et al. (2007) discussed the possible correlations of this Assemblage Zone, claiming that "the whole fauna might be intermediate between those sampled at localities of La Chilca and La Esquina, both from Los Colorados Formation, Argentina (Bonaparte 1982, Abdala et al. 2001), including the earliest records of certain clevosaurid, tritheledontian and leptopleurine clades. Alternatively, it might congregate temporally separate assemblages. Given their separated occurrences and based on their phylogenetic affinities, Jachaleria candelariensis and Sacisaurus agudoensis would be assigned to an older fauna, while Irajatherium hernandezi and Clevosaurus brasiliensis would characterize a younger one. In this case, forms that occur together with most of these taxa, such as Riograndia and brasilodontid cynodonts would have longer temporal ranges, occurring along that entire time interval". Moreover, the presence of the prosauropod Unaysaurus does not allow the correlation between São Martinho da Serra outcrop (Unaysaurus Site) with those of Faxinal do Soturno and Candelária, due to lack of similar faunal elements, but 


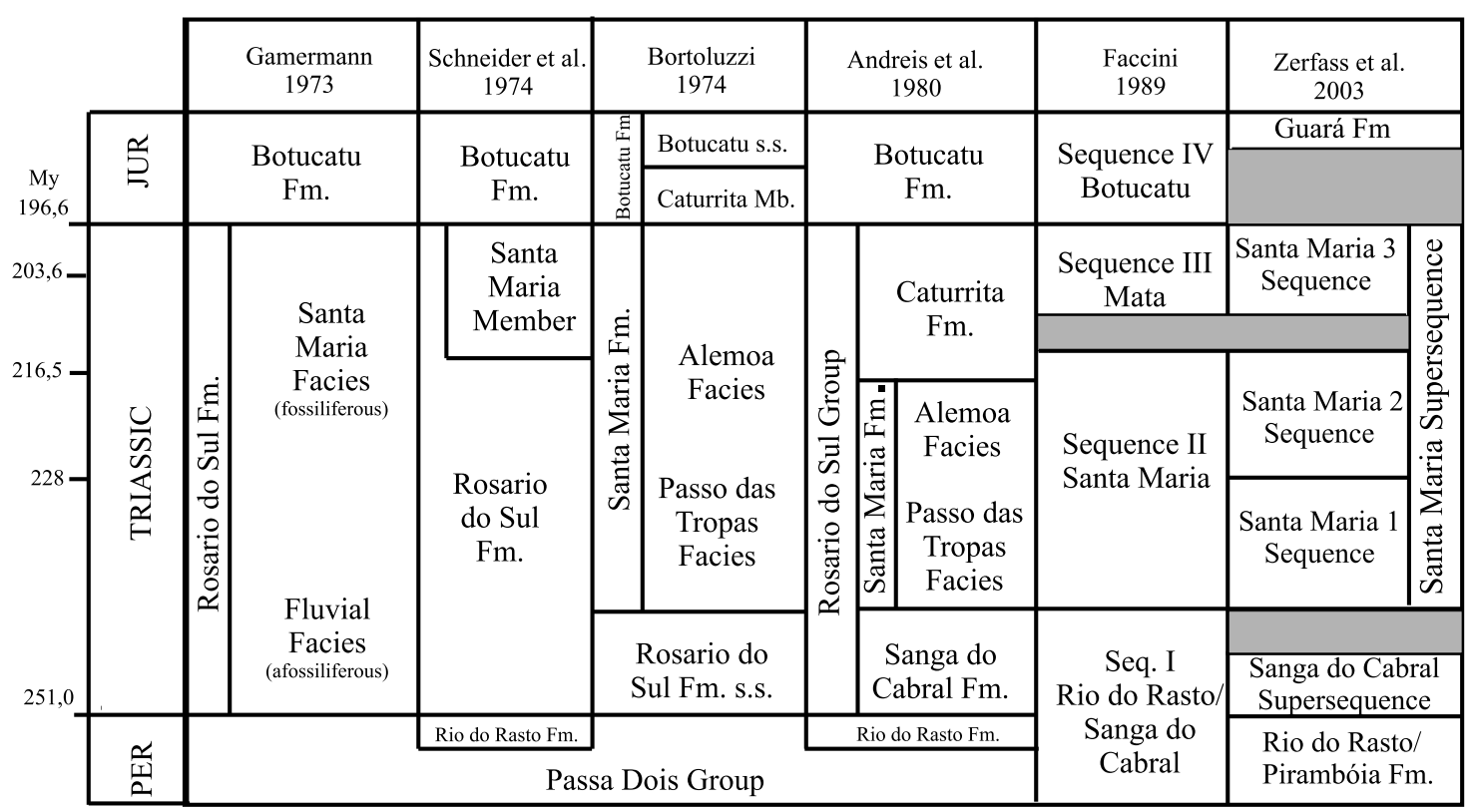

Fig. 4 - Comparative chart showing six stratigraphic proposes for the Brazilian Triassic. Riograndia guaibensis occurs in the lower portion of the Caturrita Formation (sensu Andreis et al. 1980) or in the upper portion of the Santa Maria 2 Sequence (sensu Zerfass et al. 2003). Fm., Formation; JUR, Jurassic; Mb, member; My, millions of years; PER, Permian; s.s., sensu stricto. Modified from Scherer et al. (2000). Geological Time Scale based on Gradstein and Ogg (2004).

TABLE I

Fossil record from the Santa Maria 2 Sequence, Upper Triassic of Rio Grande do Sul, Brazil.

\begin{tabular}{l|l|l}
\hline Outcrop & Localization & Fossiliferous content \\
\hline Botucaraí & Candelária & $\begin{array}{l}\text { Jachaleria, indeterminate phytosaur, } \\
\text { stereospondyl amphibian, archosaur teeth, } \\
\text { Guaibasaurus (?), Riograndia }\end{array}$ \\
\hline $\begin{array}{l}\text { Sesmaria } \\
\text { do Pinhal 1 }\end{array}$ & Candelária & $\begin{array}{l}\text { Clevosaurus, Brasilodon, Brasilitherium, } \\
\text { Irajatherium, Riograndia }\end{array}$ \\
\hline $\begin{array}{l}\text { Sesmaria } \\
\text { do Pinhal 2 }\end{array}$ & Candelária & Guaibasaurus \\
\hline $\begin{array}{l}\text { Sesmaria } \\
\text { do Pinhal 3 }\end{array}$ & Candelária & indeterminate archosaur, Brasilitherium \\
\hline Linha São Luiz & $\begin{array}{l}\text { Faxinal } \\
\text { do Soturno }\end{array}$ & $\begin{array}{l}\text { Clevosaurus, Soturnia, Cargninia, Faxinalipterus, } \\
\text { Guaibasaurus, Brasilodon, Brasilitherium, } \\
\text { Minicynodon, Irajatherium, Riograndia }\end{array}$ \\
\hline Sacisaurus Site & Agudo & Sacisaurus, Brasilitherium, Riograndia \\
\hline Unaysaurus Site & $\begin{array}{l}\text { São Martinho } \\
\text { da Serra }\end{array}$ & Unaysaurus \\
\hline
\end{tabular}

suggests a Norian age (Langer et al. 2007).

Following this point of view, Abdala and Ribeiro (2010) used the denomination Riograndia Assemblage Zone (AZ) to include the faunas of the outcrops Sesmaria do Pinhal 1, Sesmaria do Pinhal 2 and Linha São Luiz, not including the faunas of the other outcrops above listed (Table I). According to these authors, the
Riograndia AZ could be correlated with the lower fauna of the Los Colorados Formation (e.g. Jachaleria colorata), thus been interpreted as Norian, Late Norian or Rhaetic in age.

As above discussed, the hypothesis that the upper layers of the Santa Maria 2 Sequence constitute a distinct depositional sequence cannot be excluded, but there 
is no strong stratigraphic evidence for a significant discordance between this sequence and the underlying sequences that include the Hyperodapedon AZ. Besides, if a stratigraphic gap inside the Santa Maria 2 Sequence occurs, it is likely to be positioned below Jachaleria and Sacisaurus, but not between these layers and the Riograndia AZ (sensu Abdala and Ribeiro, 2010). Moreover, if the levels containing Jachaleria (as well as the phytosaur and the stereospondyl amphibian) and Sacisaurus, whose outcrops revealed also teeth of Riograndia and Brasilitherium (Ferigolo and Langer 2006), represent a fauna with a distinct age from that of the Riograndia $\mathrm{AZ}$, the choice of this taxon as a guide to name this biozone is not so suitable.

In this paper we preferred to assume that the whole fauna of the upper layers of the Santa Maria 2 Sequence constitutes a different faunal association from that occurring in the lower part of the sequence (Hyperodapedon $\mathrm{AZ}$ ) and that of the most representative taxon of this fauna, which is Riograndia guaibensis. A synthesis of our biostratigraphic opinion regarding the biostratigraphy of the South Brazilian Triassic is presented in Figure 5.

\section{DESCRIPTION AND COMPARATIVE ANATOMY}

For purposes of description, only the anatomical regions that were not mentioned by Bonaparte et al. (2001) will be presented. Also, the reinterpretation of some elements not so clear in the holotype was possible thanks to the analysis of the new materials.

\section{Medial Orbital Wall}

The medial orbital wall of Riograndia was described by Bonaparte et al. (2001). However, some new information on the ascending process of palatine and orbitosphenoid was provided by the specimens UFRGS-PV-0596$\mathrm{T}$ and UFRGS-PV-0601-T.

Palatine (Fig. 7a, b, c, d). In the medial orbital wall, the ascending process of the palatine contacts the lacrimal anteriorly and the frontal dorsally. This is very similar to that of Diarthrognathus (Crompton 1958), Elliotherium (Sidor and Hancox 2006) Therioherpeton, Prozostrodon (Bonaparte and Barberena 2001), Brasilodon (Bonaparte et al. 2003), Sinoconodon (Crompton and Luo 1993) and Morganucodon (Kermack et al. 1981).
Although this pattern is a derived condition among nonmammaliaform cynodonts, the palatine of Riograndia does not reach the development degree of tritylodontids, in which this bone is wider and contributes for the total closure of the medial orbital wall. The sphenopalatine foramen (not reported by Bonaparte et al. 2001) is enclosed by the ascending process of palatine, at the level of sixth postcanine (UFRGS-PV-0596-T). This foramen is for the passage of the major palatine nerves and vessels to the palate and the caudal nasal nerves and vessels to the nasal cavity (Wible et al. 2004). Among the non-mammaliaform cynodonts, mentions about the sphenopalatine foramen are scarce. Bonaparte and Barberena (2001) described that this opening is completely enclosed by the ascending process of palatine in the medial orbital wall of Prozostrodon, and the same pattern is observed in the tritylodontids (e.g. Bienotheroides, Sun 1984; Tritylodon, Rowe 1988; Kayentatherium, Luo 1994) and Sinoconodon (Wible 1991, Crompton and Luo 1993). In another way, Bonaparte et al. (2003) described the sphenopalatine foramen in Brasilodon, which was placed between the ascending process of palatine and orbitosphenoid as in Morganucodon.

Orbitosphenoid. No reference on the orbitosphenoid was made by Bonaparte et al. (2001) because this structure was not preserved in the holotype. None of the new materials shows evidence of an ossified orbitosphenoid, but Rodrigues et al. (2006) have confirmed the presence of this element in two specimens of Riograndia (UFRGS-PV-0596T and UFRGS-0601-T) through a comparative investigation using C.T. Scanning method. According to Rodrigues et al. (2006), the orbitosphenoid of Riograndia is less developed than that of Prozostrodon (UFRGS-PV-0248-T) and Brasilitherium (UFRGSPV-0760-T), but none of these taxa reaches the ossification degree of the tritylodontids and mammaliaforms, in which this element forms the floor of the anterior portion of the braincase (Kielan-Jaworowska et al. 2004).

\section{LATERAL WALl of BRAINCASE}

Only the specimen UFRGS-PV-0601-T (poorly preserved) exhibits the alisphenoid and the prootic anterior lamina. Additional information is provided by UFRGSPV-0596-T. 


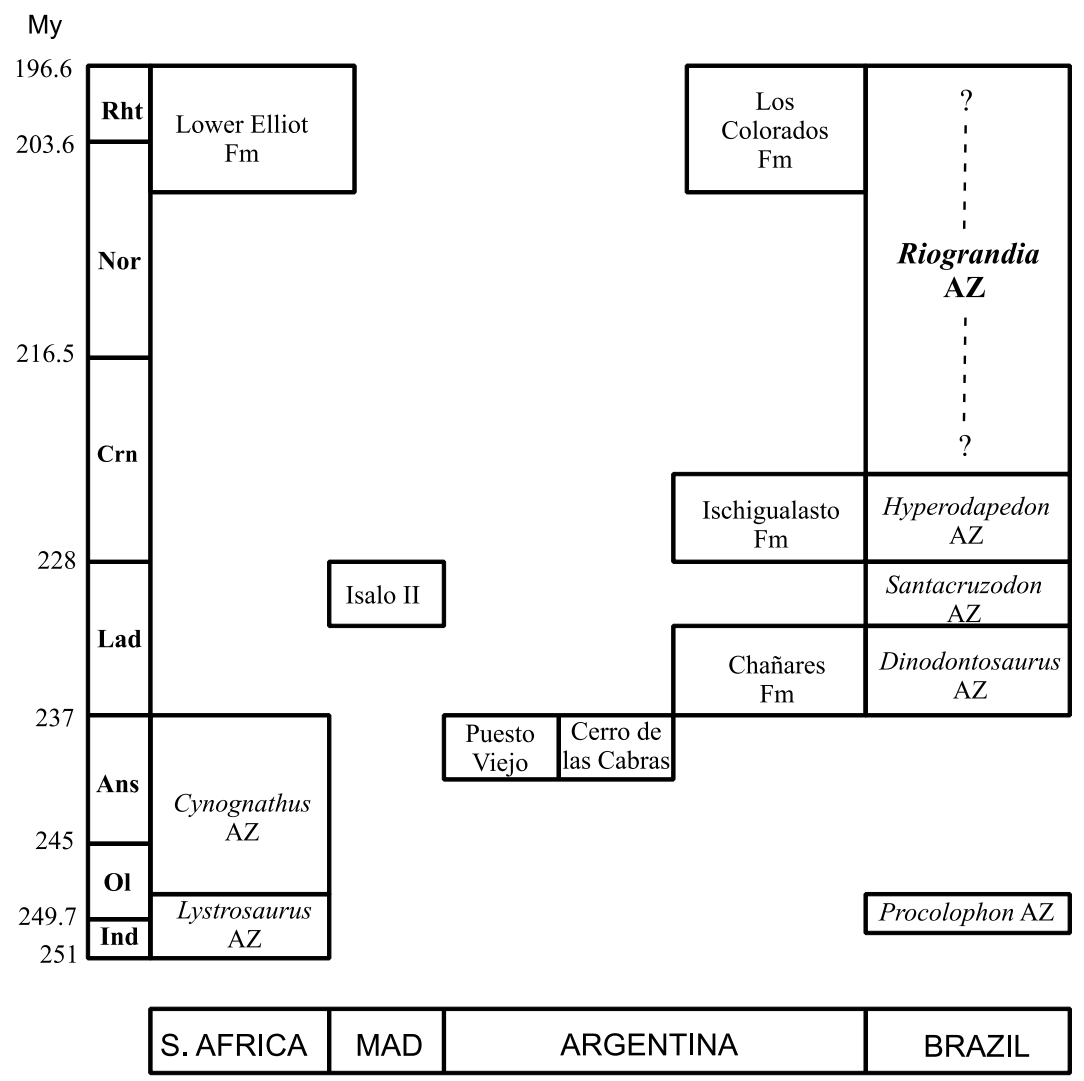

Fig. 5 - Biostratigraphic chart of terrestrial Triassic faunas from Gondwana showing the Riograndia AZ. Dinodontosaurus AZ (sensu Barberena et al. 1985), Santacruzodon AZ (sensu Abdala and Ribeiro 2010); Hyperodapedon AZ (sensu Abdala et al. 2001). Ans, Anisian; AZ, Assemblage Zone; Crn, Carnian; Ind, Induan; Lad, Ladinian; Mad, Madagascar; Nor, Norian; Ol, Olenekian; Rht, Rhaetic; S. Africa, South Africa. Modified from Abdala and Ribeiro (2010).Geological Time Scale based on Gradstein and Ogg (2004).

Parietal (Fig. 6a, b, e). The sutural relationships of the ventral border of the parietal with the elements of the braincase can be better observed in the specimen UFRGS-PV-0601-T. In lateral view, posterior to the contact with the frontal, the parietal contacts the alisphenoid and the prootic ventrally. Despite the sutures are not clear, it can be inferred that, from the frontal-parietal contact, the parietal delineates a descending bend that covers the dorsal margin of the alisphenoid and the prootic until it reaches the squamosal. Along the ventral margin of the parietal, in contact with the prootic and the alisphenoid, a narrow and shallow open groove is placed. The groove is not well defined in its origin, but its posterior end appears to be near the position of the pterygoparoccipital foramen (in the prootic). The position of this groove suggests that it corresponds to the sinus canal or orbitotemporal canal, which passes the ramus supraor- bitalis of the stapedial artery. Riograndia shares the plesiomorphic condition, an opened orbitotemporal canal, with other non-mammaliaform cynodonts (Wible and Hopson 1993) excepting tritylodontids (Hopson 1994).

Squamosal (Fig. 6a, b, e). The cranial area comprised by the squamosal is very restricted. In the posteriormost portion of the temporal region, the squamosal contacts the anterior lamina of the prootic anteriorly and the parietal dorsally. Its anterodorsal limit is situated at the level of the anterior opening of the posttemporal canal, which is placed in the prootic-squamosal suture. Posteriorly, the squamosal borders dorsally on the obliquely descending parietal. There is no evidence of a place to the articulation with the quadrate-jugal in the squamosal of Riograndia. The remains from the glenoid in the UFRGS-PV-0596-T permit to observe that it is 
a concave area, more anteriorly rather than ventrally directed, resembling that of Pachygenelus (Luo and Crompton 1994), Sinoconodon (Crompton and Luo 1993) and Hadrocodium (Luo et al. 2001).

Quadrate (Fig. 6a, b). In the holotype of Riograndia (Bonaparte et al. 2001) the quadrate is not preserved. The information of this element comes from a fragmented right quadrate, which is displaced from its natural position, of UFRGS-PV-0596-T. When observed in anterior or posterior view, the quadrate shows a triangular shape, resembling that of Probainognathus (Romer 1970), but being slender. In Riograndia, the trochlear area is less expanded than that of Probainognathus, a fact that gives an elongated aspect for the quadrate that is unusual among non-mammaliaform cynodonts. The trochlea presents a cylindrical shape and its convex articular facet contacts the concave area of the articular bone. In its ventral surface, the trochlea bears a pair of elongated condyles, the medial trochlear condyle, and the lateral one, which is wider than the former as in Procynosuchus (Kemp 1979), Thrinaxodon (Fourie 1974), Probainognathus (Romer 1970), among others. A lateral notch is situated above the lateral trochlear condyle, which separates the trochlea of the lateral margin of the articular facet of the dorsal plate without forming a neck, as in Thrinaxodon and Probainognathus. The dorsal plate of Riograndia's quadrate shows a sharper dorsal angle than in Pachygenelus and Morganucodon (whose quadrate exhibits a rounded dorsal margin), resembling more the pattern of Probainognathus. The articular facet of the dorsal plate is concave as in Probainognathus, Massetognathus, tritylodontids, Pachygenelus and Morganucodon (Luo and Crompton 1994). Differing from Probainognathus, in which the quadrate articulates with the alisphenoid, the quadrate of Riograndia is exclusively suspended by the squamosal as in the tritheledontids Diarthrognathus and Pachygenelus (Crompton 1958, Crompton and Hylander 1986, Allin and Hopson 1992, Luo 1994, Luo and Crompton 1994). Moreover, the quadrate of Riograndia was not covered by the squamosal in lateral view, as in Diarthrognathus, Chiniquodon and traversodontids; this bone is exposed as in Probainognathus, which would provide a better mobility (Romer 1970). There is no stapedial process in the quadrate of Riograndia. Regarding this character it is similar to other tritheledontids (Luo and Crompton 1994), but different from Brasilodon and Brasilitherium (Bonaparte et al. 2005, Luo 2007).

Alisphenoid (Fig. 6e). The alisphenoid is identified in two specimens (UFRGS-PV-0596-T and UFRGS-PV0601-T). In lateral view, the ascending process of the alisphenoid is a spatulated plate. In its dorsal border, the ascending process shows an anterior expansion that meets the ventroposterior margin of the frontal. It seems that the alisphenoid-frontal contact in Riograndia occupies a wider area than that of Pachygenelus (Wible and Hopson 1993), Brasilodon and Brasilitherium (Bonaparte et al. 2003, 2005), similarly to the patterns observed in Diartrognathus (Crompton 1958), Sinoconodon (Crompton and Luo 1993) and Morganucodon (Kermack et al. 1981). The major part of the anterior margin of the alisphenoid delimitates the posterior border of the sphenorbital fissure, as in most non-mammaliaform cynodonts, excepting in tritylodontids (Luo 1994). Below the contact with the frontal, the ascending process of alisphenoid becomes narrower near its base as in Morganucodon (Kermack et al. 1981). Throughout its anterior margin, a well-defined thin vertical ridge is delimited, resembling that of Diarthrognathus (Crompton 1958). The suture between the alisphenoid and the parietal has been already mentioned. The specimen UFRGS-PV-0601-T shows that Riograndia exhibits the general feature of non-mammaliaform cynodonts that is the ascending process of the alisphenoid being anteroposteriorly broad and widely in contact with the anterior lamina of the prootic. The alisphenoid quadrate ramus is preserved in the specimens UFRGS-PV0601-T and UFRGS-PV-0833-T, and will be described together with other basicranial elements.

Prootic (Fig. 6e). The prootic of Riograndia is laterally projected, forming a lateral flange that is supported by the quadrate ramus of the alisphenoid. This lateral flange is well developed as in Pachygenelus (Wible and Hopson 1993), but does not exhibit a vertical component as in tritylodontids (Hopson 1964). The anterior lamina of the prootic, better preserved in the specimen UFRGSPV-0601-T, meets the posterior margin of the alisphenoid ascending process anteriorly, the parietal dorsally, and the squamosal posteriorly. There is no clear indi- 
a
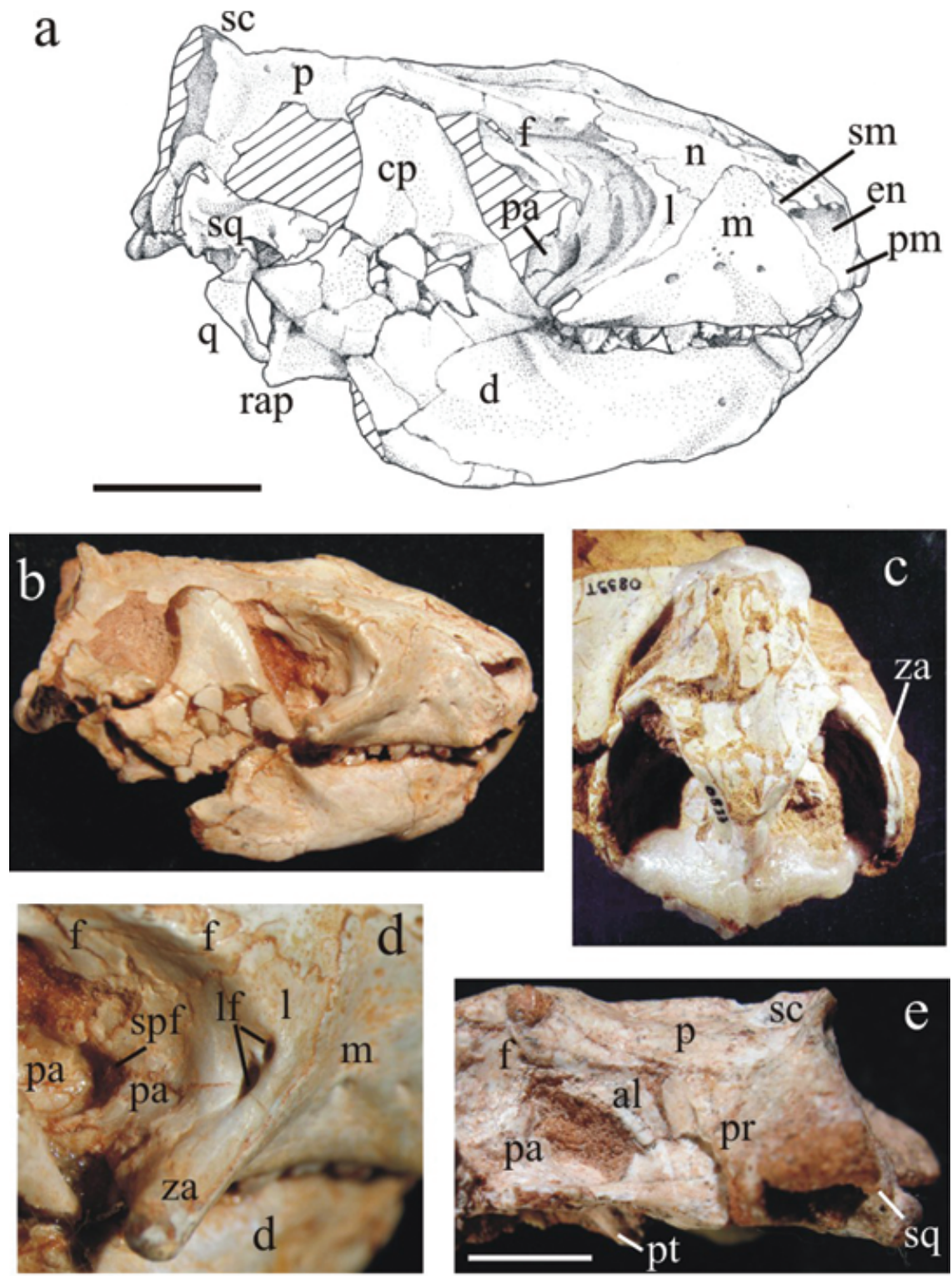

Fig. 6-Riograndia guaibensis. UFRGS-PV-0596-T in lateral view: (a) drawing and (b) photo; (c) UFRGS-PV-0833-T in dorsal view; (d) UFRGS-PV-0596-T, detail of the medial orbital wall; (e) UFRGS-PV-0601-T in lateral view. Scale bar = $10 \mathrm{~mm}$. al, alisphenoid; cp, coronoid process; d, dentary; en, external naris; f, frontal; 1, lacrimal; lc, lambdoidal crest; lf, lacrimal foramen; m, maxilla; n, nasal; p, parietal; pa, palatine; pm, premaxilla; pr, prootic; pt, pterygoid; q, quadrate; rap, retroarticular process; sc, sagittal crest; sm, septomaxilla; so, supraoccipital; spf, sphenopalatine foramen; sq, squamosal; za, zygomatic arch.

cation of the location for the exit for the maxillar (V2) and mandibular (V3) branches of the trigeminal nerve. In lateral view, the ventrally opened pterygoparoccipital foramen is reached by the alisphenoid quadrate ramus in its anteroventral margin, but in most of its part this opening is enclosed by the anterior lamina of the prootic. Above the dorsal border of the pterygoparoccipital foramen an excavated area, forming a groove, is visible. At the end of this groove, between the anterior lamina of the prootic and the squamosal, the small anterior opening of the posttemporal canal is placed. We infer that the pterygoparoccipital foramen and the an- 
terior opening of the posttemporal canal communicated through this groove, which corresponds to the open channel for the passage of the superior ramus of the stapedial artery and other vessels that exit through the pterygoparoccipital foramen (Rougier et al. 1992). Thus, in Riograndia it seems that these blood vessels should run in an open channel in the lateral flange of the prootic until they join the sinus canal system (orbitotemporal canal) and posttemporal veins (Wible and Hopson 1993). This is the same configuration as in Pachygenelus (Wible and Hopson 1993). However, the open ascending channel for the superior ramus of the stapedial artery is different and more primitive than the enclosed channel of this vessel in mammaliaforms, such as Morganucodon (Wible and Hopson 1993) and Hadrocodium (Luo et al. 2001).

\section{ZYGOMATIC ARCH (FIG. 6C, D)}

At least in one of the new specimens, UFRGS-PV0833-T, the zygomatic arches are preserved in all of their length. Some information, related to the root of the zygomatic arch, was also provided by the specimen UFRGS-PV-0596-T. The specimen UFRGS-PV-0833-T confirms the suggestion of Bonaparte et al. (2001) that the zygomatic arch of Riograndia is slender. In a general way, the zygomatich arch resembles that of Pachygenelus, whose arch delineates, in lateral view, a straight line. The prominent zygomatic process of the maxilla, at the expense of the anterior process of the jugal, constitutes an important element of the suborbital region of the skull of Riograndia. This is a condition also presented by other tritheledontids (Hopson and Barghusen 1986), Brasilodon (Bonaparte et al. 2003) and mammals (Luo 1994). In the root of the zygomatic arch, the maxilla contacts posteriorly the jugal and medially the lacrimal. The lacrimal of Riograndia occupies a large area in the root of the zygomatic arch as in Chaliminia (Bonaparte 1980, Martinelli and Rougier 2007), Diarthrognathus (Crompton 1958) and Pachygenelus (Bonaparte et al. 2003). The lacrimal-jugal contact in the root of the zygomatic arch is much reduced in lateral view due to the presence of the zygomatic process of maxilla that covers the jugal laterally. The lacrimal of Riograndia seems to contribute in the root of the zygomatic arch in the same way as Brasilodon (Bonaparte et al.
2003), Morganucodon (Kermack et al. 1981), Sinoconodon (Crompton and Luo 1993) and the docodont Haldanodon (Lillegraven and Krusat 1991), in which this bone and the maxilla rather than the jugal are the dominant elements. The weak representation of the jugal in the root of the zygomatic arch showed by Riograndia contrasts with the general non-mammaliaform cynodont pattern whose jugal is the dominant element. Regarding the dorsal extension of the zygomatic arch, Riograndia presents the same condition of most non-mammaliaform cynodonts (excepting traversodontids and tritylodontids) and mammaliaforms, in which the maximal dorsal height of the arch is situated in a plane below half of the orbit (Hopson and Kitching 2001). The squamosal zygomatic portion is positioned in the middle of the the arch, overlying the jugal, and configures a dorso-ventrally compressed bar exhibiting the same depth of the jugal. Due to the lateral curvature of the squamosal and the jugal, the zygomatic arch of Riograndia shows, in dorsal view, a round shape, with its maximal lateral projection placed in the middle of the arch, as in Thrinaxodon (Fourie 1974), Probainognathus (Romer 1970), Pachygenelus (Allin and Hopson 1992), and Brasilodon (Bonaparte et al. 2003), among others.

\section{PALATE}

The secondary osseous palate was described by Bonaparte et al. (2001); the specimens UNISINOS-4881 and UFRGS-PV-0596-T bring additional information. The primary palate has received little description by previous authors and is well represented in UFRGS-PV-0596-T, UFRGS-PV-0833-T and UNISINOS-4881.

Palatine (Fig. 7a, b). In its posteriormost portion, the palatal plate becomes broader, following the general trend of the whole skull. The contribution, in extension, of the palatine in the secondary palate is greater than that of the maxilla. The former makes up to $50 \%$ of the length of the postcanine row, the same derived condition of other tritheledontids, tritylodontids (KielanJaworowska et al. 2004), Brasilodon (Bonaparte et al. 2003, 2005) and Morganucodon (Kermack et al. 1981). The posterior edge of the palatal plate of the palatine surpasses the level of the posterior limit of the maxillary tooth row as in the other tritheledontids and mammals (Hopson and Barghusen 1986). In each side of 
the palate, the greater palatine foramen is symmetrically positioned, very close to the suture between the maxilla and the palatine (but completely enclosed by the palatine). These structures, considered apomorphic for epicynodonts (Hopson and Barghusen 1986, KielanJaworowska et al. 2004), served as a passage of the greater palatine branch of the sphenopalatine nerve (a branch of the maxillary ramus of the trigeminal nerve) and the greater palatine artery (Kermack et al. 1981, Rougier et al. 1992). In front of the anterior border of these foramina, there is a shallow groove that surpasses the anterior limit of the palatine and reaches the maxilla, where the nerve and the artery should run forward together. Posteriorly to the greater palatine foramina, in the same symmetric position, there are two smaller foramina, which should correspond to the lesser palatine foramina, only reported in tritylodontids among non-mammaliaform cynodonts (Kemp 1983, KielanJaworowska et al. 2004). In this group, the foramina are placed in the same position of those from Sinoconodon (Crompton and Luo 1993) and Morganucodon (Kermack et al. 1981), that is, near the posterolateral limit of the palatine, behind the last postcanine level. In Riograndia this second pair of palatine foramina is placed more medially behind the great palatine foramina at the level of the last postcanine. Both pairs of foramina are clearly present in the secondary palate of the two specimens of Riograndia (UFRGS-PV-0596-T and UNISINOS-4881) and the holotype, which was confirmed in the reexamination done by the senior author. In this sense, Riograndia shares with Tritylodontidae and Mammaliaformes the derived condition of the presence of a lesser palatine foramen (Luo 1994, Kielan-Jaworowska et al. 2004). The posterior palatal plate of the palatine forms the floor and the lateral walls of the posterior portion of the nasopharyngeal cavity (Kermack et al. 1981, Hopson and Barghusen 1986). This region is well preserved in the specimen UNISINOS-4881, but some information was also provided by UFRGS-PV-0596-T. In the medial region of the primary palate of the last specimen, the palatine projects posteriorly, contacting medially the vomer. The posteriormost portion of the palatine is enclosed medial and laterally by the pterygoids. At the limit between these two bones, in both sides of the primary palate, two lateral ridges are defined. These ridges converge medially until reaching the posterior margin of the palatine. The lateral pterygopalatine ridges of Riograndia are parts of a system of ridges that will be discussed in the description of the pterygoid.

Pterygoid (Figs. 6e; 7a, b). The pterygoids are relatively well preserved in three specimens, UFRGS-PV0596-T, UFRGS-PV-0601-T and UNISINOS-4881. No specimen shows the contact of pterygoid with the maxilla or the vomer. Laterally, in the anterior portion of the pterygoids, the pterygoid flanges are placed. The pterygoid flanges of Riograndia are smaller than those of Pachygenelus (Bonaparte et al. 2003) and have a triangular shape, with the apex directed ventroposteriorly, which allows a lateral contact with the mandible. In the specimen UFRGS-PV-0596-T the pterygoid flanges are in close contact with the region of the supposed coronoid bone of the lower jaw. In the medial region of its anterior portion the pterygoids are a little concave. The meeting of the two pterygoids in the sagittal plane defines a medial ridge. This ridge reaches anteriorly the internal nares area. At the level of the interpterygoid vacuity the medial ridge suffer an interruption, but it is reconstituted posteriorly until it reaches the basisphenoid. Symmetrically placed in each side of the medial ridge, the pterygopalatine (or intermediate) ridges run parallel to it without keeping contact. These structures correspond to the site of the attachment of the anterior pterygoid muscle, which promotes a stronger union between palate and neurocranium (Kemp 1982). The pterygopalatine ridges border laterally the interpterygoid vacuities and reach the anterior margin of the basisphenoid as in Pachygenelus and Morganucodon (Luo 1994). Kermack et al. (1981) affirm that the medial ridge of Morganucodon does not reach the internal nares region, but they suggest that this region would be divided by a cartilaginous septum. In Riograndia there is no sign of a bone wall between the internal nares either. Thus, we can infer that Riograndia should also present a kind of connective tissue dividing the air passages. Between the medial ridge and both pterygopalatine ridges, two channels are formed. Another pair of channels is delimited in each side of the pterygopalatine ridges. Riograndia presents a palatal system of ridges and channels very similar to those of Pachygenelus (Luo 1994), tritylodontids (Young 1947), and Morganucodon and multituberculates (Kielan-Jaworowska 1971). Several authors (e.g. Watson 1921, Kermack 1956, KielanJaworowska 1971, Kermack et al. 1981, Barghusen 
1986, Maier et al. 1996) infer that this system would be covered by soft tissue, extending the length of the secondary palate and dividing the nasopharyngeal cavity into two air passages: lateral and medial. The interpterygoid vacuities of Riograndia correspond to a well-defined structure that was crossed by the cultriform process of the basisphenoid. Some very thin and small bone fragments dispersed in the interpterygoid vacuity area of UFRGS-PV-0596-T could indicate that the aperture was covered by an incipient sheet of bone. Among epicynodonts, the interpterygoid vacuities were observed in juveniles specimens of Thrinaxodon (Martinelli and Rougier 2007), and among eucynodonts this feature is present in juveniles of Probelesodon and Lumkuia, in adult specimens of tritheledontids, as Diarthrognathus (Crompton 1958), Chaliminia (Bonaparte 1980, Martinelli and Rougier 2007) and Pachygenelus (Hopson and Barghusen 1986), and in Brasilodon and Brasilitherium (Bonaparte et al. 2005). The presence of the interpterygoid vacuities in epicynodonts has been interpreted as a retention of a primitive character or a reversion to a plesiomorphic therapsid condition, which was still conserved in the pre-epicynodonts Dvinia and Procynosuchus (Hopson and Barghusen 1986). According to Kemp (1979), the vacuities are a remnant structure related to some skull kinetism of basal therapsids still present in these Permian cynodonts. Martinelli and Rougier (2007) have considered that the re-acquisition of the interpterygoid vacuities in the derived nonmammaliaform cynodonts, which bear a high resemblance with the pattern present in most basal forms (e.g. Procynosuchus) and in immature individuals of more derived forms (e.g. Thrinaxodon, Lumkuia, Probelesodon, Kayentatherium), could be the result of heterochronic processes like paedomorphosis. We consider that, in the case of Riograndia and other tritheledontids, it is plausible to accept that the presence of the interpterygoid vacuity is a consequence of the new remodeling of the primary palate, in connection with the increase of the nasopharyngeal system and brain, then to assume that the vacuity is related with skull kinetism as in primitive cynodonts. So, instead of being interpreted as a homoplastic feature shared with pre-epicynodonts, the interpterygoid vacuities of Riograndia and other tritheledontids should be interpreted as an evolutionary novelty. Despite the presence of the interpterygoid vacuities, the primary palate of Riograndia, formed by transversely enlarged pterygoids, is similar to that of other tritheledontids and Morganucodon. The broadening of the primary palate is related with an evolutionary trend observed in the advanced non-mammaliaform eucynodonts, which includes an increase in the cerebral volume and an inflation of the nasopharyngeal system, promoting the posterior displacement of the choanas and the separation of the pterygopalatine ridges (Rowe 1993). Regarding the pterygoid quadrate ramus, it is possible to observe in the specimens UFRGS-PV-0601$\mathrm{T}$ and UNISINOS-4881 that each pterygoid shows a lateral inflexion, becoming more convex posterioly. At this point, the pterygoids seem to be fused to the alisphenoid and, from there, a posterolateral projection can be observed. As the suture between these two bones is indistinguishable, it is probable that the mentioned projection corresponds to the alisphenoid quadrate ramus. This condition is in agreement with the eucynodontia general pattern, which is the reduction or lack of the pterygoid quadrate ramus (Hopson and Barghusen 1986). No sign of an ectopterygoid was observed in the specimens of Riograndia, as in other thitheledontids, tritylodontids and basal mammaliaforms (e.g. Sinoconodon and Megazostrodon).

\section{BASICRANIUM}

Three studied skulls (UFRGS-PV-0596-T, UFRGS-PV0833T, UNISINOS-4881) reveal information on the basicranium.

Basisphenoid-parasphenoid complex (Fig. 7a, b). In a general way these elements follow the basic nonmammaliaform cynodont pattern, with a triangular outline, displaying a greater transverse development in the posterior sector. The well-developed basipterygoid process is defined in the left side of the skulls UFRGS-PV0596-T and UNISINOS-4881; it forms the anteromedial margin of the ventral opening of the cavum epiptericum and contacts anteriorly the pterygoids. The parasphenoid overlaps the basisphenoid, covering this bone ventrally in all of its extension. The limit between the basisphenoid and basioccipital can be only described based on the basioccipital anterior articular facet. The facet shows that the contact between these two bones was delineated by a lightly curved suture, concave in the medial portion and convex in the lateral portions. Although the basisphenoid wing (parasphenoid ala) 
was not completely preserved in any of the specimens, we can infer that it was reduced because the area situated in both sides of the basisphenoid is occupied by the prootic in the specimens UFRGS-PV-0596-T and UFRGS-PV-0833-T. Riograndia shares with Probainognathus (Romer 1970, Allin 1986), chiniquodontids (Romer 1969, Teixeira 1982), Diarthrognathus (Crompron 1958), Pachygenelus (Luo 1994) and tritylodontids (Sues 1986) the derived condition that is a reduced basisphenoid wing excluded from the margin of the fenestra ovalis. The basisphenoid wing of Riograndia is more reduced than that of Diarthrognathus (Crompton 1958), resembling more that of Pachygenelus (Bonaparte et al. 2003). However, it is not as reduced as in mammaliaforms, such as Adelobasileus (Lucas and Luo 1993, Luo et al. 1995), and Hadrocodium (Luo et al. 2001). The cultriform process of the parasphenoid was not conserved in any of the specimens, although signs of ossification of the basisphenoid-parasphenoid complex, medial to the cavum epiptericum, reveal a short ridge. Probably the ossification that forms this ridge corresponds to the basisphenoid, which was originally fused to the parasphenoid and projects anteriorly through its cultriform process. Based on the medial pterygoid ridges, we can infer that the cultriform process of Riograndia would extend anteriorly between the pterygoids, lying over the referred ridge and crossing the interpterygoid vacuities until joining the vomer. In the area of origin of the medial pterygoid ridge of UFRGSPV-0596-T it is possible to observe remnants of bone adhered in both sides, which may correspond to pterygoid fragments that were originally fused to the parasphenoid and basisphenoid. The fusion of these elements is characteristic of advanced non-mammaliaform eucynodonts and Morganucodon (Kermack et al. 1981). This feature is also related to the cranial anatomical remodeling observed along the evolutionary history of the Cynodontia, in function of the increase of the cerebral and nasopharyngeal system volume as discussed in the case of the interpterygoid vacuities. The transversal enlargement of the pterygoids and its fusion to the cultriform process of the parasphenoid in Riograndia illustrates this evolutionary trend, which is fully established in Morganucodon (Kermack et al. 1981). About the position of the internal carotid foramina, the specimen UFRGS-PV-0596-T shows clearly these small openings, placed symmetrically in the medial portion of the basisphenoid.
Alisphenoid (Fig. 7d). The anterior margin of the alisphenoid cannot be observed because it is broken in the only specimen that bears this bone partially preserved (UFRGS-PV-0601-T). The quadrate ramus of the alisphenoid projects posteriorly and covers the pterygoid and the prootic laterally. In ventral view, the quadrate ramus of the alisphenoid participates on the formation of the lateral border of the cavum epiptericum and projects posteriorly until the level of the anterior margin of the basioccipital, but without surpassing it. Riograndia shares this feature with other tritheledontids and non-mammaliaform cynodonts, excepting tritylodontids (Rowe 1988), which present the plesiomorphic condition.

Basioccipital (Fig. 7e). About the basioccipital, no previous information was provided by the holotype of Riograndia (Bonaparte et al. 2001). The basioccipital, preserved in the specimens UFRGS-PV-0596-T and UFRGS-PV-0601-T, presents a typical hexagonal shape, but wider anteriorly. In its median portion there is a short prominent and thickened ridge that runs along the bone surface. In consequence, the basiocipital lateral margins are depressed. In the central portion of the bone there are two small nutritional foramina. Based on the anterior contact facet of the basioccipital, we can see that this bone meets the basisphenoid-parasphenoid complex through an anteriorly concave suture line. Laterally, the basioccipital meets the prootic through a diagonal suture that converges anteriorly to the sagittal plane. The posteriormost sector of the basioccipital participates on the ventral border of the foramen magnum. The sutures between basioccipital and exoccipitals are wide and run anterioly diagonal to the sagittal plane.

Exoccipital (Fig. 7c, e). The exoccipitals of Riograndia are preserved in the specimens UFRGS-PV-0596-T, UFRGS-PV-0601-T, UFRGS-PV-0833-T. In the basicranium, the contact between the exoccipital and the paroccipital process of the opisthotic is located laterally to each occipital condyle, below half of the extension of the posterior margin of the jugular foramen. Near the posterolateral margin of the jugular foramen there are two foramina for the hypoglossal nerve (XII) passage, one situated more anteriorly and the other, more posteriorly. The general pattern exhibited by non-mammalia- 
form cynodonts is the hypoglossal foramina in confluence with the jugular foramen. The derived condition presented by Riograndia is also observed in Oligokyphus (Kühne 1956), Pachygenelus (Bonaparte et al. 2003) and Brasilitherium (Bonaparte et al. 2005). However, one can verify that the ossified area between the jugular foramen and the hypoglossal foramina ("jugular process" of Kermack et al. 1981) in Pachygenelus, Brasilitherium and mammaliaforms is wider than that in Riograndia (Lucas and Luo 1993, Luo et al. 2001).

Prootic and opisthotic (Fig. 7d, e). The prootic and the opisthotic are partially represented in the basicranium of UFRGS-PV-0596-T, UFRGS-PV-0601-T and UFRGSPV-0833-T. Riograndia presents the primitive condition of unfused prootic and opisthotic, a feature evidenced by the specimen UFRGS-PV-0833-T, in which both elements are preserved around the pterygoparoccipital foramen. Perpendicular to the posterior margin of this foramen, we can observe a vertical straight line that should correspond to the suture between the prootic and the opisthotic. The supposed suture is situated in a similar position to the suture between the prootic and the opisthotic of Probainognathus and Chiniquodon (Abdala 1996). Regarding tritheledontids, Wible (1991) has made reference to a visible suture between these two bones in a juvenile specimen of Pachygenelus, but no conclusion about the character state of adult individuals was possible to establish. In Diarthrognathus, Crompton (1958) affirms that there is no sign of suture dividing the prootic and the opisthotic. In Brasilodon (Bonaparte et al. 2005), the prootic and the opisthotic are separated. The tritylodontids Oligokyphus (Crompton 1964) and Kayentatherium (Sues 1986) show these two elements fused, as in Brasilitherium (Bonaparte et al. 2005) and mammaliaforms (e.g. Morganucodon, Sinoconodon and Hadrocodium), whose fused prootic and opisthotic form the petrosal bone (Luo et al. 1995). The suture between the paroccipital process and the exoccipital is placed laterally to the occipital condyle (UFRGS-PV0833T). The paroccipital process does not meet the quadrate because the latter bone is in contact exclusively with the squamosal. This is the same plesiomorphic state presented by Probainognathus, Massetognathus, Diarthrognathus and Pachygenelus (Luo and Crompton 1994), in which the paroccipital process is laterally covered by the squamosal. The laterally opened pterygo- paroccipital foramen of Riograndia (UFRGS-PV-0833$\mathrm{T}$ ) is anteriorly bordered by the prootic and posteriorly by the paroccipital process, as in Pachygenelus (Wible and Hopson 1993). Running laterally to the prootic, the alisphenoid quadrate ramus posteriormost limit reaches the anterior margin of the pterygoparocipital foramen, but without covering it. Riograndia follows the same pattern of Pachygenelus (Wible and Hopson 1993), tritylodontds (Lucas and Luo 1993, Luo 1994), morganucodontids and Sinoconodon (Wible and Hopson 1993).

In Riograndia, the jugular foramen is separated from the fenestra rotunda (or perilymphatic foramen) by a narrow bone bar. This separation is a derived condition among non-mammaliaform cynodonts, being shared with tritylodontids (e.g. Tritylodon, Oligokyphus) (Rowe 1988), Pachygenelus (Wible 1991) and Brasilitherium (Bonaparte et al. 2005). However, in the last two taxa, the distance between the jugular foramen and the fenestra rotunda is wider than in Riograndia. The posterior and lateral margins of the jugular foramen are dominated by the paroccipital process, while the anterior and medial ones are formed by the prootic. The fenestra ovalis is a large opening (greater than the jugular foramen and the fenestra rotunda), totally enclosed by the prootic and positioned lateroanteriorly to the jugular foramen and the fenestra rotunda (without contacting the basisphenoid wing), a derived state shared with Probainognathus (Luo 1994), chiniquodontids (Romer 1969), Diarthrognathus (Crompton 1958), Pachygenelus (Allin 1986) and mammaliaforms (Luo 1994). Despite this derived condition, the fenestra ovalis of Riograndia still has an osseous ring, which is a primitive condition of non-mammaliaform cynodonts (Luo et al. 1995). This ring, which contacts the stapes, is a common feature among non-mammaliaform cynodonts (e.g. Probainognathus, Luangwa, Massetognathus, Kayentatherium, Diarthrognathus). The cavum epiptericum is posteromedially bordered by the prootic, laterally by the alisphenoid quadrate ramus and anteriorly by the basipterygoid process of the basisphenoid. Only a very narrow ossified portion separates the anterior margin of the fenestra ovalis from the cavum epiptericum. Thus, as in most part of the non-mammaliaform cynodonts [excepting Probainognathus (Luo 1994), Exaeretodon (Abdala et al. 2002) and tritylodontids (Hopson 1964, Kemp 1983)], the cavum epiptericum of Riograndia does not form a floor. 

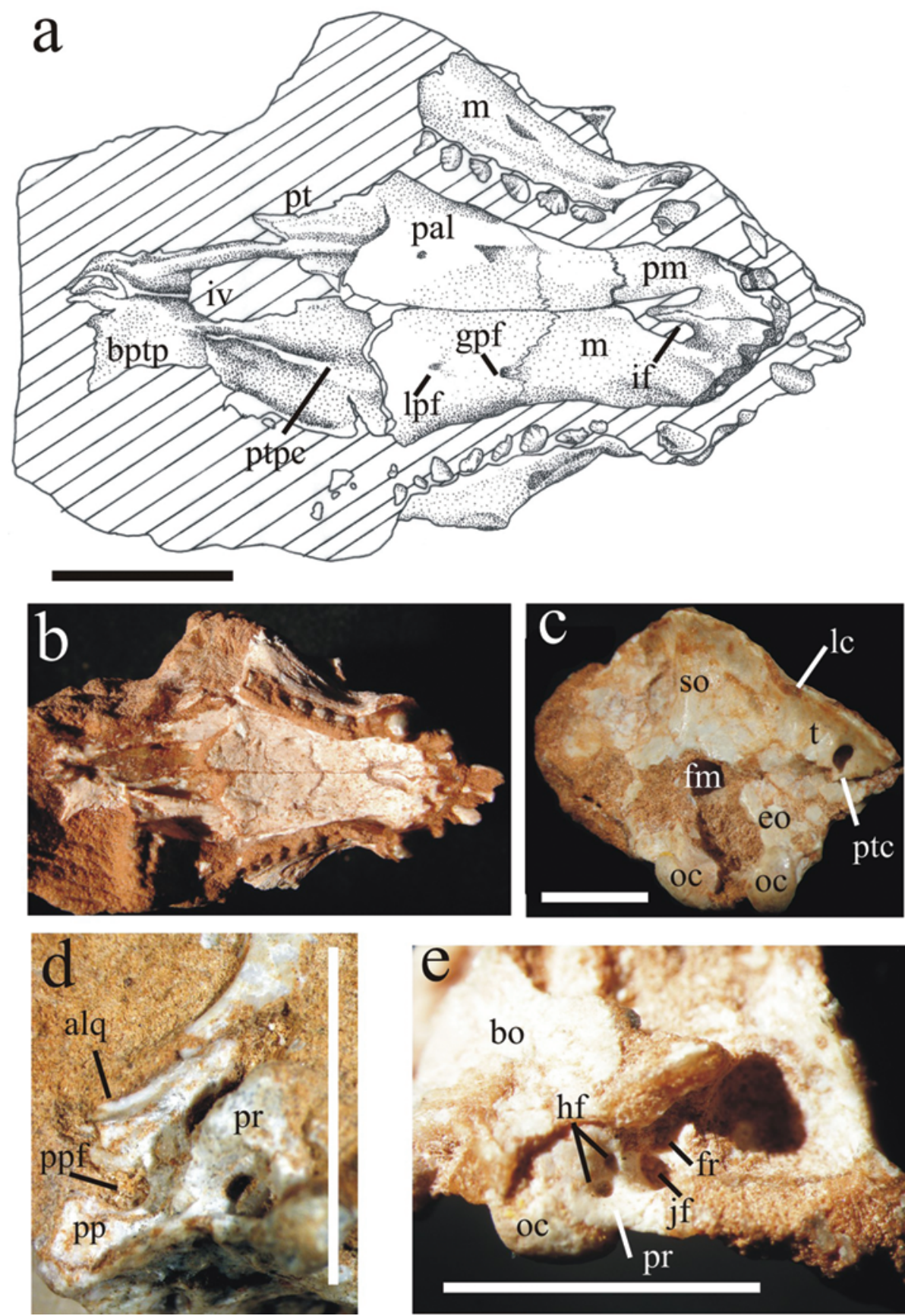

Fig. 7 - Riograndia guaibensis. UNISINOS-4881 in ventral view: (a) drawing and (b) photo; (c) UFRGS-PV0596-T in posterior view; (d) UFRGS-0833-T in ventral view, detail of the basicranium; (e) UFRGS-0596-T in ventral view, detail of the basicranium. Scale bar $=10 \mathrm{~mm}$. alq, alisphenoid quadrate ramus; bptp, basipterygoid process; bo, basioccipital; fm, foramen magnum; fr, fenestra rotunda; gpf, great palatine foramen; hf, hypoglossal foramina; if, incisive foramina; iv, interpterygoid vacuity; jf, jugular foramen; lc, lambdoidal crest; lpf, lesser palatine foramen; m, maxilla; oc, occipital condyle; t, tabular; pa, palatine; pm, premaxilla; pp, paroccipital process; ppf, pterygoparoccipital foramen; pr, prootic; pt, pterygoid; ptc, posttemporal canal; ptpc, pterygopalatine crest. 
Squamosal. In UFRGS-PV-0596-T the squamosal notch, to lodge the quadrate, is placed laterally to the contact between the squamosal and the paroccipital process, and medially to the glenoid cavity. The facet on the paroccipital process for the squamosal is parallel to the sagittal plane. Its cranial moiety does not extend anteriorly to the level of the posterior margin of the pterygoparoccipital foramen, which is not encircled by the squamosal.

\section{OCCIPITAL REGION}

Comparisons with other tritheledontids are difficult because the occipital region is poorly preserved in Diarthrognathus (Crompton 1958), Chaliminia (Bonaparte 1980) and Elliotherium (Sidor and Hancox 2006); no published data about Pachygenelus is available. The specimens UFRGS-PV-0596-T and UFRGS-PV-0601$\mathrm{T}$ have conserved the whole occipital region. In lateral view, the ventral margin of the occipital plate is more posteriorly projected than the dorsal one. In posterior view, the occipital plate shows a triangular shape, with the apex delimited by the union of the sagittal and lambdoidal crests.

Interparietal. Due to the high level of fusion of the occipital plate, the presence of an interparietal cannot be observed in UFRGS-PV-0596T, which has the best preserved skull roof and occipital region. Riograndia seems to follow the pattern showed by other advanced non-mammaliaform cynodonts as Diarthrognathus (Crompton 1958), Pachygenelus (Luo 1994), Therioherpeton (Bonaparte and Barberena 1975, 2001), tritylodontids (Rowe 1988) and mammaliaforms (Lucas and Luo 1993), which lack an independently ossified interparietal.

Supraoccipital (Fig. 7c). The supraoccipital is strongly fused to the other occipital plate elements. The sagittal and lambdoidal crests project over the supraoccipital; throughout the medial portion of the bone a broad and short ridge is delineated, supporting the sagittal crest and promoting a greater robustness of this portion of the occipital plate. In each side of the medial ridge there are two shallow depressed areas that correspond to sites of muscular attachment. The supraoccipital seems to be restricted to the dorsal margin of the foramen magnum, whose lateral margins are delimitated by the exoccipitals. The suture between the supraoccipital and the tabulars is not clear, but the former contacts laterally the latter.

Basioccipital (Fig. 7e). The posteriormost portion of the basioccipital participates on the ventral border of the foramen magnum. In occipital view, the basioccipital separates the two occipital condyles through a shallow notch. This feature represents a derived condition shared with Chiniquodon (Abdala 1996), Lumkuia (Hopson and Kitching 2001), Pachygenelus (Bonaparte et al. 2003), Brasilodon and Brasilitherium (Bonaparte et al. 2003, 2005), among others. However, in Riograndia and in these mentioned taxa, a well-developed notch for the odontoid process of the axis, like that of Adelobasileus (Lucas and Luo 1993), Sinoconodon (Crompton and Luo 1993) and Morganucodon (Kermack et al. 1981), has not been formed yet.

Tabular (Fig. 7c). The tabular of Riograndia occupies the whole area lateral to the supraoccipital, being limited dorsolaterally by the descending lambdoidal crests of parietals and laterally by the squamosal. Ventrolaterally each tabular makes contact with the paroccipital process, and ventromedially contacts the exoccipitals. Both posttemporal canals, through which the arteria and the vena diploetica magna pass (Wible and Hopson 1993), are dorsally encircled by the tabulars very close to the squamosal margin. The ventral margin of each posttemporal canal touches the suture between the tabular and the paroccipital process, being, thus, bordered by the exoccipitals. This condition, shared with Probainognathus (Romer 1970), Diarthrognathus (Crompton 1958), Pachygenelus (Lucas and Luo 1993), Brasilodon (Bonaparte et al. 2003), and Oligokyphus (Crompton 1964), among others, is considered by Luo (1994) as intermediate between the plesiomorphic condition, characterized by a posttemporal canal totally encircled by the tabular; and the derived condition exhibited by mammaliaforms, in which the posttemporal canal is dorsally bordered by the squamosal.

Exoccipital (Fig. 7c, e). The suture between the exoccipitals and the supraoccipital is located at the level of the dorsal border of the foramen magnum, perpendicular to the sagittal plane, but it is almost indistinguishable due to the great degree of fusion of the whole occiput. It seems that the exoccipitals border the foramen magnum laterally, while its dorsal border is dominated by the supraoccipital, as mentioned before. The shape of 
the occipital condyles of Riograndia is oval, similar to the pattern observed in Pachygenelus (Bonaparte et al. 2003). The condyles do not reach the top of the dorsal border of the foramen magnum, being restricted to its ventral one-third, which is a primitive condition (Rowe 1988). As mentioned above, the occipital condyles are well separated by the posterior margin of the basioccipital. Following the general pattern of the whole occipital plate, we can observe that the ventral portion of the condyles is more posteriorly projected than the dorsal one. This condition is also observed in the occipital plate of Adelobasileus (Lucas and Luo 1993). The nonbifurcated paroccipital process occupies the base of the occipital plate, lateral to each occipital condyle. Dorsally, the paroccipital process makes an irregular contact with the tabular and borders the ventral margin of the posttemporal canal, as mentioned before.

\section{LOWER JAW}

Bonaparte et al. (2001) have described the almost complete lower jaw of the specimen MCN-PV2265 in the medial view, but nothing was reported about the postdentary bones of Riograndia. All the new specimens (UFRGS-PV-0596-T, UFRGS-PV-0624T, UFRGS-PV0833T, UFRGS-PV-0623T) confirm the characteristics observed in the type series (Bonaparte et al. 2001): a mandible with rather robust construction with a high and thick unfused symphysis, a high coronoid process and a distinct angular process. The postdentary bones complex of Riograndia is described for the first time in this contribution.

Postdentary bones (Fig. 8e). The information about the postdentary bones of Riograndia comes from the specimens UFRGS-PV-0596-T, UFRGS-PV-0624-T and UFRGS-PV-0833-T. The postdentary trough is dorsally limited by the medial ridge of the dentary that runs anteriorly until the level of pc6. Posteriorly, the medial ridge becomes wider and projects above the articular process, which represents the posteriormost edge of the dentary. However, the articular process of the dentary does not form a condyle as seen in mammaliaforms. The relative position of the articular process of the dentary of Riograndia (Fig. 1c) is more dorsal than the dorsal margin of the postcanines row, a derived feature shared with traversodontids, tritylodontids (Bonaparte 1962, Crompton and Sun 1985), Pachygenelus (Allin and Hopson 1992), Diarthrognathus (Crompton 1963), Chaliminia (Bonaparte 1980, Martinelli and Rougier 2007) and Morganucodon (Kermack et al. 1981). All the three specimens that have preserved the postdentary bones show some degree of fragmentation in these elements, but in general we can observe that the surangular, angular, articular and prearticular compose a fragile unity, lodge in the postdentary trough, as in other advanced non-mammaliaform eucynodonts and mammaliaforms (Crompton and Luo 1993). The articular, prearticular and angular are fused, as in other tritheledontids (Allin and Hopson 1992). Supposedly, the surangular runs parallel over the rod formed by the articular, prearticular and angular, and finishes at the posteriormost level of the retroarticular process. The articular seems to form most part of the retroarticular process, which is concave and exhibits the ventral margin posteriorly projected. The reflected lamina of the angular was not preserved, and there is no evidence of a contact between the surangular and the squamosal in any of the analyzed specimens. Regardind the craniomandibular joint, it seems that Riograndia presents the same condition of other tritheledontids (Luo and Crompton 1994) and Brasilitherium (Bonaparte et al. 2003), that is the articular process of the dentary in contact with the squamosal, instead of the surangular, as in most eucynodonts (Crompton 1958, 1972). Thus, the dentary-squamosal articulation (or contact) represents a synapomorphy of Tritheledontidae, Brasilitherium and mammaliaforms (Luo 1994, Luo 2007). The splenial, which should cover medially the Meckelian groove, was not preserved in any of the specimens. Only in the UFRGS-PV-0596-T was possible to distinguish a most medially pronunciated area in the medial face of the mandible that can suggest the presence of the coronoid bone.

\section{Dentition (Fig. 8A, B, C, D, E)}

The dental anatomy of Riograndia has received special treatment by Bonaparte et al. (2001). The authors have considered that Riograndia shows a plesiomorphic tooth morphology when compared to other tritheledontids. According to Bonaparte et al. (2001), the upper dentition of MCN-PV2264 comprises three procumbent incisors (upper incisor 2 and lower incisor 1 are the largest), with the enamel present only on the buccal side of the incisors. Both upper and lower canines are re- 

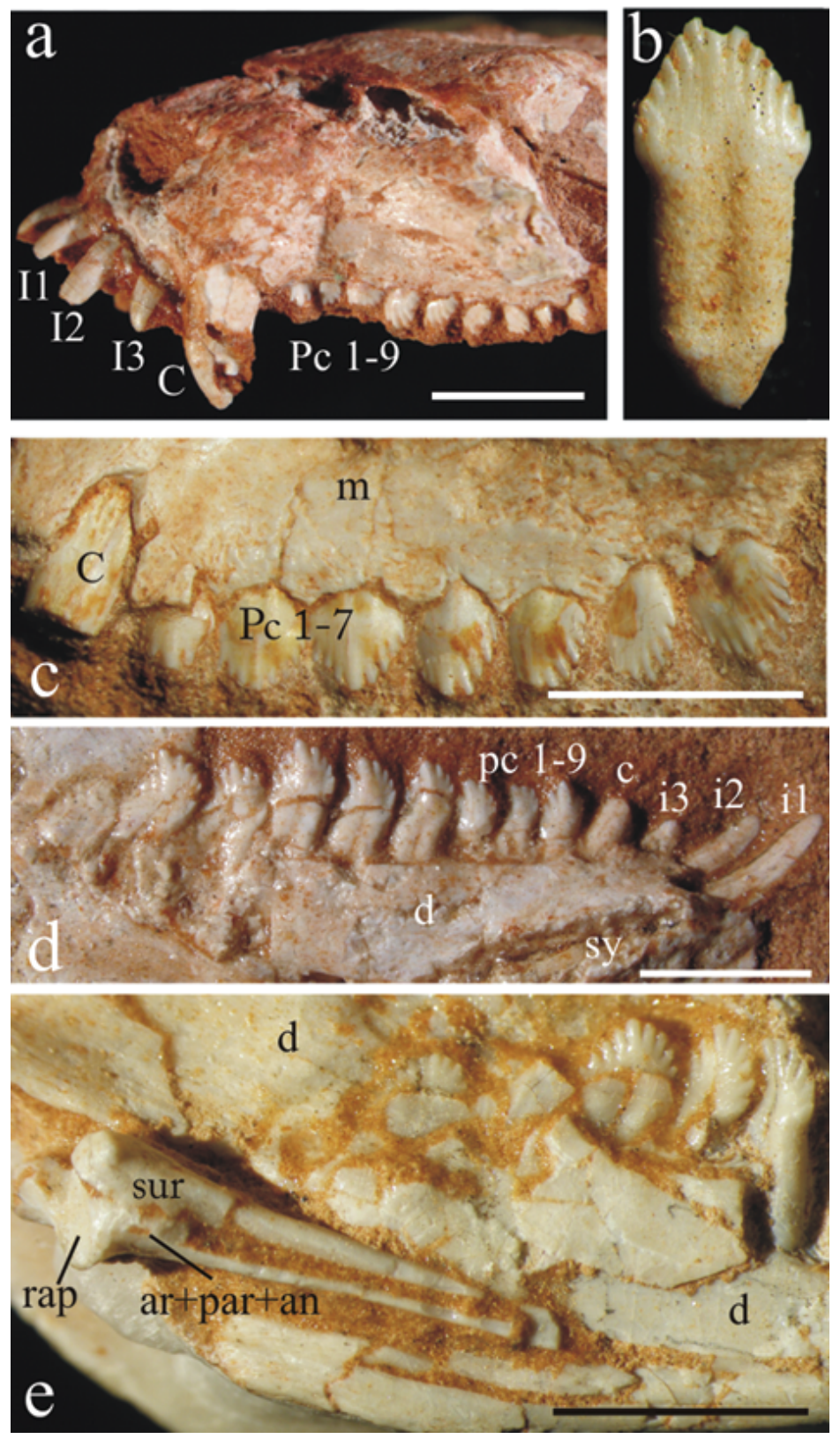

Fig. 8 - Riograndia guaibensis. (a) UNISINOS-4881 in lateral view; (b) UFRGS-PV-0842-T in lingual view; (c) UFRGS-PV-0788-T, right maxilla in lateral view with detail of the upper dentition; (d) UFRGS-PV- 0622-T, right mandible in lingual view with detail of the lower dentition; (e) UFRGS-PV-0833-T, right mandible in lingual view with detail of the postdentary bones. Scale Bar $=10 \mathrm{~mm}$. ar, articular; an, angular; c, lower canine; C, upper canine; $\mathrm{d}$, dentary; i, lower incisor; I, upper incisor; m, maxilla; par, prearticular; pc, lower postcanine; Pc, upper postcanine; rap, retroarticular process; sur, surangular.

duced in size. The postcanines are blade-like, with six to nine aligned cuspules, each of them bordered by a shallow groove. On the buccal side the central cuspules are usually the largest. The postcanine roots presented an incomplete subdivision, suggesting an incipient bi- furcation. There is no cingulum in the postcanines. The new specimens of Riograndia show the same dental pattern, but also indicate that there is a trend for an increase of the size in the last upper and lower postcanines, like in Diarthrognathus, Pachygenelus and Ira- 
jatherium. Some dental series (e.g. UFRGS-PV-0622$\mathrm{T}, 788-\mathrm{T}$ ) show that, in upper and lower postcanines, the cuspules are slightly displaced posteriorly and curved backwards. This curvature is better defined in the central cusp and in the distal accessory cuspules. Tritheledontids as Pachygenelus (Gow 1980) and Irajatherium (Martinelli et al. 2005) also show the postcanines cusps recurved backwards. The dentition of the newly studied specimens confirms the description of Bonaparte et al. (2001), excepting for the upper canine size. Despite the fact that the canines are small in UFRGS-PV-0596$\mathrm{T}$, these elements are well developed in the specimens, UNISINOS-4881 and UFRGS-PV-0788-T, showing that these teeth are much more robust than the incisors in the upper dentition. The same was observed by Sidor and Hancox (2006) in Elliotherium, and by Oliveira et al. (2010) in Irajatherium, differing from Pachygenelus and Diarthrognathus that are characterized by small upper canines. The cranial size of the cited new specimens is greater than the type specimens (MCN-PV2264, MCN-PV2265) and UFRGS-PV-0596-T. This suggests that this variation is due to differences in ontogenetic stages exhibited by the analyzed specimens. In regard to the lower canines, in all available jaws these elements keep a small size as reported by Bonaparte et al. (2001). Most of the analyzed teeth show an intense wear suggesting slow replacement rates and/or a diet based on fibrous food itens. With respect to this, Cabreira (2009) inferred that Riograndia was not a carnivore/insectivore animal, as postulated by Bonaparte et al. (2001), but a herbivore one. According to the author, the maxilomandibular aparattus of this taxon, characterized by a very developed chisel-shaped lower incisor (i1) and with open roots and leaf-like postcanines, points out to a "rodent" dietary habit.

\section{CONCLUSION}

A complete diagnosis of the Tritheledontidae clade, as well as a fully understanding of the relationships among its members, was still not possible due to the incomplete state of most taxa in the group (e.g. Chaliminia, Diarthrognathus, Tritheledon). In this sense, many phylogenetic analyses code the character states of Pachygenelus (some of them not published yet) as representative of all tritheledontids.

Fortunately, the description of the new taxon El- liotherium, a description of a new specimen of Chaliminia (Martinelli and Rougier 2007) and the study of new materials of Irajatherium (Oliveira et al. 2010) have increased the knowledge about the Tritheledontidae. Now, the detailed description of several new specimens of Riograndia from this contribution makes this taxon one of the most complete, known for nearly all anatomical regions of the skull and dentition, of tritheledontids.

Riograndia shows important anatomical characters that are quite derived among the eucynodonts, mainly those of the medial orbital wall, lateral wall of the braincase, basicranium, secondary osseous palate, primary palate and craniomandibular joint. Many of these characters constitute synapomorphies shared only with other tritheledontids and their closely related taxa, which includes tritylodontids, Brasilodon, Brasilitherium and Mammaliaformes.

In a recent cladistic analysis, Riograndia is considered the most basal tritheledontid (Martinelli et al. 2005). In regard with the phylogenetic position of Riograndia in the Tritheledontidae Clade, Sidor and Hancox (2006) noted that the highly distinctive dental features were responsible for the basal position of this taxon because its postcanines lack a more bulbous shape and cingulum, features present in other tritheledontids. We recognize that the dental characteristics have an important phylogenetic significance, in agreement with Sidor and Hancox (2006), and we consider the dental characteristics of Riograndia to be derived instead of generalized, as pointed out by Bonaparte et al. (2001). We follow the view of Cabreira (2009) that the spatulated (leaf-like) postcanine teeth with significant wear and inferior first incisor with an open root are products of the adaptative features related with a herbivore diet. It is likely that Riograndia is more advanced than previously thought. Thus, we presume that the use of the new cranial and mandibular anatomical information about Riograndia, decribed in the present study, in future cladistic analysis, will make possible a more accurate understanding of its phylogenetic position and provide a more solid representation of the characters of the Tritheledontidae.

Regardless of its phylogenetic placement inside Tritheledontidae, Riograndia illustrates an important stage of the evolutionary history of the Eucynodontia Clade closely related to the mammalians' origins. Rowe 
(1993) made comments about the anatomical transformations that ocurred in the group comprising the tritheledontids, tritylodontids and mammaliaforms. According to the author, this group bears one of the most distinctive and strongly diagnosed taxa within Cynodontia. Rowe (1993) postulates that virtually all parts of the skeleton were remodeled in association with a dramatic reduction in body size. In this sense, the cranial reorganization involved inflation of the nasopharyngeal cavity, remodeling of the orbit, further enclosure of the brain, and further modifications of the acoustic and masticatory systems. Similar to other tritheledontids (and tritylodontids), Riograndia shows a wider skull roof as compared to other non-mammaliamorpha eucynodonts. This derived feature is also reflected in the long osseous secondary palate and in the broad and long primary palate with wide interpterygoid vacuities. The development of a more extensive medial orbital wall formed by the contact between the frontal and the palatine, an ossified orbitosphenoid and the development of the prootic anterior lamina provide a better enclosure of the brain. A more sophisticated basicranium with complete separation of the jugular foramen and the fenestra rotunda and a possible contact between the dentary and the squamosal associated with the reduction of the postdentary bones to a thin rod and an unfused symphysis, revelead advances in both auditory and masticatory systems. In fact, the cerebral volume of Riograndia (UFRGSPV-596-T and 601-T) was inferred by Rodrigues et al. (2006) through C.T. Scanning method using nasal cavities and braincases. The obtained data, concerning morphological aspects, showed that this taxon had high respiratory rates and significant encephalization, which suggests their elevated metabolic status.

The Triassic members of the Mammaliamorpha (sensu Kielan-Jaworowska et al. 2004) clade have a wide distribution in the South American continent (Rio Grande do Sul and Argentina). Riograndia, Irajatherium and Chaliminia demonstrate that many derived characters, considered synapomorphies of Mammaliamorpha, were already established before the end of the Triassic, when the tritheledontids and mammaliaforms just started their diversification.This geographic area during the Triassic time (maybe inside Carnian) was where the evolution of the most profound anatomical transformation occurred in the cynodont-mammal transition.

In addition to the phylogenetic and evolutionary approach, a second contribution of the record of Riograndia in South American Upper Triassic is to allow the biostratigraphic relationships of the whole fauna of the "Caturrita Formation" or upper portion of the Santa Maria 2 Sequence through the association of its taxa in the Riograndia AZ. This biozone reflects an important moment in the beginning of the evolutionary history of both dinosaurs and mammaliamorpha, just before the two taxa spread out across the Pangea. The anchorage of the Riograndia AZ enhances the more accurate temporal correlations with other Triassic faunas of Gondwana and Laurasia.

\section{ACKNOWLEDGMENTS}

We especially thank Jose Fernando Bonaparte, for the useful comments and suggestions. We acknowledge Tania Dutra and Ana Maria Ribeiro for the access of the UNISINOS and FZBRS collections, respectively. Mirian Reichel for the drawings and Luiz Flávio Lopes for the photos. Alexandre Liparini, Tiago Raugust, Alessandra Boos and Téo Veiga de Oliveira for the assistance in the elaboration of this paper. We also acknowledge the Fundação de Amparo à Pesquisa do Estado do Rio Grande do Sul (FAPERGS) for the partial financial support. We are also greatful to Zhe Xi Luo and Liu Jun for important suggestions and critical reading on the final version of this manuscript.

\section{RESUMO}

O triteledontídeo Riograndia guiabensis foi o primeiro cinodonte descrito para a fauna da "Formação Caturrita" do Triássico Superior do sul do Brasil (Sequência Santa Maria 2). Os materiais da série-tipo não forneceram informações anatômicas relativas à caixa craniana, ociput, basicrânio, arco zigomático, ossos pós-dentários e articulação crânio-mandibular. Neste artigo são descritos novos materiais que suprem as informações anatômicas não contempladas anteriormente. Riograndia apresenta um conjunto de importantes aspectos anatômicos derivados dentre os eucinodontes não-mammaliaformes, tais como fechamento parcial da parede orbital medial e da caixa craniana, extenso palato ósseo secundário, palato primário alargado, basicrânio com separação do forame jugular e da fenestra rotunda, arco zigomático estreito e ossos pós-dentários extremamente reduzidos. Muitas destas feições constituem sinapomorfias compartilhadas somente com os demais membros do clado Mammaliamorpha. Assim, as praticamente com- 
pletas informações crânio-mandibulares e dentárias de Riograndia trazem uma significante contribuição ao conhecimento da anatomia dos triteledontídeos e suas relações filogenéticas e auxiliam na elucidação sobre os passos transformacionais envolvidos na transição cinodonte-mamífero. Adicionalmente, Riograndia figura como um táxon-chave no refinamento bioestratigráfico da "Formação Caturrita", através da integração de vários afloramentos fossilíferos os quais apresentam uma rica fauna de tetrápodes que pode ser correlacionada com outras faunas triássicas do Gondwana e da Laurásia.

Palavras-chave: Formação Caturrita, Cynodontia, Triássico Superior, Riograndia, Tritheledontidae.

\section{REFERENCES}

ABDALA F. 1996. Redescripción del cráneo y reconsideración de la validez de Cynognathus minor (Eucynodontia, Cinognathidae) del Triásico Inferior de Mendoza. Ameghiniana 33(2): 115-126.

Abdala NF. 2007. Redescription of Platycraniellus elegans (Therapsida, Cynodontia) from the Lower Triassic of South Africa, and the cladistic relationships of eutheriodonts. Palaeontology 50(3): 591-618.

Abdala NF, BARberena MC AND Dornelles JE. 2002. A new species of traversodontid cynodont Exaeretodon from the Santa Maria Formation (Middle/Late Triassic) of Southern Brazil. J Vert Paleont 22(2): 313-325.

AbDala NF AND Ribeiro AM. 2010. Distribution and diversity patterns of Triassic cynodonts (therapsida, Cynodontia) in Gondwana. Palaeogeogr Palaeoclimatol Palaeoecol 286: 202-217.

Abdala NF, Ribeiro AM And Schultz CL. 2001. A rich cynodont fauna of Santa Cruz do Sul, Santa Maria Formation (Middle-Late Triassic), southern Brazil. Neues Jahrbuch für Geologie und Paläontologie, Monatshefte, p. 669-687.

ALLIN EF. 1986. The auditory apparatus of adavanced mammal-like reptiles and early mammals. In: HоTTON III N ET AL. (Eds), The ecology and biology of mammal-like reptiles. Smithsonian Inst Press, p. 283-294.

ALLIN EF AND Hopson JA. 1992. Evolution of the auditory system in Synapsida ("Mammal-like Reptiles and primitive Mammals") as seen in the fossil record. In: WESTER DB ET AL. (Eds), The evolutionary biology of hearing, New York: Springer-Verlag, USA, p. 587-614.

Andreis R, Bossi G AND Montardo D. 1980. O Grupo Rosário do Sul (Triássico) no Rio Grande do Sul. In: Congresso Soc. Bras. Geologia 31, Anais, Camboriú, 2: 659-673.
ARAÚJO DC AND GonZAGA TD. 1980. Uma nova espécie de Jachaleria (Therapsida, Dicynodontia) do Triássico do Brasil. In: Congreso Argentino de PALEONTOLOGIA Y BioESTRATIGRAFIA, II CONGRESO LATInoAmericano de Paleontologia. Actas, Buenos Aires, UBA, p. 159-174.

Barberena MC, Araújo DC, LaVina EL and AzeveDo SK. 1985. O estado atual do conhecimento sobre os tetrápodes permianos e triássicos do Brasil Meridional. In: VIII Congresso Brasileiro de PAleontoloGIA, 1983. Rio de Janeiro, Coletânea de Trabalhos Paleontológicos, Série Geologia, Seção Paleontologia e Estratigrafia, Brasília 27(2): 21-28.

BARGHUSEN H. 1986. On the evolutionary origin of the therian sensor veli palatini and tensor tympani muscles. In: HotTON III N ET AL. (Eds), The ecology and biology of mammal-like reptiles. Smithsonian Inst Press, p. 253262.

Bonaparte JF. 1962. Descripción del cráneo y mandíbulas de Exaeretodon frenguelli, Cabrera, y su comparación con Diademodontidae, Tritylodontidae y los cinodontes sudamericanos. Publ Mus Mun C Nat y Trad Mar del Plata 1: $135-402$.

Bonaparte JF. 1970. Annotated list of South American Triassic tetrapods. In: $2^{\text {nd }}$ SYMPOSIUM ON GONDWANA STRATIGRAPHY, 1970, Proceedings and Papers, Pretoria, p. 665-682.

BONAPARTE JF. 1980. El primer ictidosaurio (Reptilia-Therapsida) de America del Sur, Chaliminia musteloides, del Triásico Superior de La Rioja, Argentina. In: II CONgreso Argentino de Paleontología y BioesTRATIGRAFÍA Y I CONGRESO LATINOAMERICANO DE Paleontología, Actas 1: 123-133.

BONAPARTE JF. 1982. Faunal replacement in the Triassic of South America. J Vert Paleont 2: 362-371.

Bonaparte JF AND BARBERENA MC. 1975. A possible mammalian ancestor from the Middle Triassic of Brazil (Therapsida, Cynodontia). J Palaeontol 49: 931-936.

Bonaparte JF AND BARberena MC. 2001. On two advanced carnivorous Cynodonts from the Late Triassic of Southern Brazil. Bull Mus Comp Zool 156(1): 59-80.

BonAparte JF, BREA G, SCHUltz CL AND MARTINELli AG. 2006. A new specimen of Guaibasaurus candelariensis (basal Saurischia) from the Late Triassic Caturrita Formation of southern Brazil. Hist Biol, p. 1-10.

Bonaparte JF, Ferigolo J And Ribeiro AM. 1999. A new Early Late Triassic saurischian dinosaur from Rio Grande do Sul State, Brazil. National Sciences Museum Monographs 15: 89-109. 
Bonaparte JF, Ferigolo J And Ribeiro AM. 2001. A primitive Late Triassic 'ictidosaur' from Rio Grande do Sul, Brazil. Palaeontology 44(4): 623-635.

Bonaparte JF, Martinelli A, Schultz CL and RUBERT R. 2003. The sister group of mammals: small cynodonts from the Late Triassic of Southern Brazil. Rev Bras Paleontol 5: 5-27.

Bonaparte JF, Martinelli AG, Schultz CL AND RUBERT R. 2005. New information on Brasilodon and Brasilitherium (Cynodontia, Probainognathia) from the Late Triassic, southern Brazil. Rev Bras Paleontol 8: 25-46.

Bonaparte JF, Schultz CL, SoAres MB AND MarTINELli A. 2010. La fauna local de Faxinal do Soturno, Triásico Tardío de Rio Grande do Sul, Brazil. Rev Bras Paleontol 13(3): 1-14.

Bonaparte JF And Sues HD. 2006. A new species of Clevosaurus (Lepidosauria: Rhynchocephalia) from the Upper Triassic of Rio Grande do Sul, Brazil. Palaeontology 49: 917-923.

BORTOLUZZI CA. 1974. Contribuição à geologia da região de Santa Maria, Rio Grande do Sul, Brasil. Pesquisas 4(1): $7-86$.

CABreira SF. 2009. Anátomo-histologia ósteo-dentária básica do Tritheledontidae Riograndia guaibensis Bonaparte et al. 2001 (Therapsida, Eucynodontia): implicações no estudo da emergência e integração dos caracteres mamalianos. Programa de Pós-Graduação em Geociências, Universidade Federal do Rio Grande do Sul, Tese de Doutorado, $290 \mathrm{p}$.

Cisneros JC And Schultz CL. 2003. Soturnia caliodon n. g. n. sp., a procolophonid reptile from the Upper Triassic of Southern Brazil. Neues Jahrb Geol Paläontol 227: $365-380$.

CROMPton AW. 1958. The cranial morphology of a new genus and species of ictidosaurian. Proc Zool Soc London 130: $183-216$.

Crompton AW. 1963. On the lower jaw of Diarthrognathus and the origin of the mammalian lower jaw. Proc Zool Soc London 140: 697-753.

CROMPTON AW. 1964. On the skull of Oligokyphus. Bulletin of the British Museum (Natural History). Geology 9: 7082 .

CROMPton AW. 1972. Evolution of the jaw articulation in cynodonts. In: JoYSEY KA AND KEMP TS (Eds), Studies in Vertebrate Evolution, Edinburgh, Oliver \& Boyd, p. 231-253.

Crompton AW AND Hylander WL. 1986. Changes in mandibular function following the acquisition of a dentary-squamosal jaw articulation. In: HotTON III N
ET AL. (Eds), The ecology and biology of mammal-like reptiles, Washington DC, Smithsonian Inst Press, p. $2263-2282$.

Crompton AW AND Luo ZX. 1993. Relationships of the Liassic mamals Sinoconodon, Morganucodon oehleri and Dinnetherium. In: SzALAY FS ET AL. (Eds), Mammal Phylogeny: Mesozoic differentiation, Multituberculates, Monotremes, Early Therians, and Marsupials, Springer Verlag, New York, p. 30-44.

CROMPTON AW AND SUN A. 1985. Cranial structure and relationships of the Liassic mammal Sinoconodon. Zool J Linn Soc Lond 85: 99-119.

DiAs-DA-Silva S, Dias EV and Schultz CL. 2009. First record of stereospondyls (Tetrapoda, Temnospondyli) in the Upper Triassic of Southern Brazil. Gondwana Research 15(1): 131-136.

DORNELLES JF. 1990. Registro sobre a ocorrência de dentes de um arcossáurio para a Formação Caturrita, Triássico Superior do Rio Grande do Sul. Ciência \& Natura 12: 99-101.

FACCINI UF, SCHERER CMS AND NowATZKi CH. 1995. Breve panorama sobre a estratigrafia do Permo-Triássico da borda sudeste da Bacia do Paraná: conjecturas e refutações. Com Mus Cien Tecn UBEA/PUCRS. Ser Cien Terra 1: $13-18$.

Ferigolo J And LAnger MC. 2006. A Late Triassic dinosauriform from south Brazil and the origin of the ornithischian predentary bone. Hist Biol 19(1): 23-33.

FOURIE S. 1974. The cranial morphology of Thrinaxodon liorhinus Seeley. Annals of the South African Museum 65: 337-400.

Furin S, Preto N, Rigo M, Roghi G, Gianolla P, CROWLey JL AND Bowring SA. 2006. High-precision $\mathrm{U}-\mathrm{Pb}$ zircon age from the Triassic of Italy: Implications for the Triassic time scale and the Carnian origin of calcareous nannoplankton and dinosaurs. Geology 34(12): 1009-1012.

Gow CE. 1980. The dentitions of Tritheledontidae (Therapsida: Cynodontia). Proc Roy Soc Lond B 208: 461-481.

GradsteIn FM AND OGG JC. 2004. Geological Time Scale 2004 - why, how and where next! Lethaia 37: 175-181.

HOPSON JA. 1964. The braincase of the advandced mammallike reptile Bienotherium. Postilla, 87: 1-30.

HopSON JA. 1991. Systematics of the nonmammalian Synapsida and implications for patterns of evolution in synapsids. In: Schultze HP AND TRUeB L (Eds), Controversial views on the origins of the higher categories of tetrapods. Cornell University Press, Ithaca, p. 635-693. 
Hopson JA. 1994. Synapsid Evolution and the Radiation of Non-Eutherian Mammals. In: PROTHERO DR AND SCHOCH RM (Eds), Major features of Vertebrate Evolution (Short Courses in Paleontology), Paleontological Society 7: 190-219.

HOPSON JA AND BARGHUSEN H. 1986. An analisys of therapsid relationships. In: HotTON III N ET AL. (Eds), The ecology and biology of mammal-like reptiles, Washington DC, Smithsonian Inst Press, p. 83-106.

Hopson JA AND KitChING JW. 1972. A revised classification of cynodonts (Reptilia; Therapsida). Palaeontol Afr 14: 71-85.

Hopson JA AND KITCHING JW. 2001. A probainognathian cynodont from South Africa and the phylogeny of nonmammalian cynodonts. Bull Mus Comp Zool 156: 5-35.

KEMP TS. 1979. The primitive cynodont Procynosuchus: functional morphology of the skull and relationships. Phil Trans Roy Soc Lond B 288: 217-258.

KEMP TS. 1982. Mammmal-like reptiles and the origin of mammals, Academic Press, London, 363 p.

KEMP TS. 1983. The relationships of mammals. Zool J Linn Soc Lond 77: 353-384.

KERMACK KA. 1956. Tooth replacement in mammal-like reptiles of the suborders Gorgonopsida and Therocephalia. Phil Trans Roy Soc Lond B 149: 204-215.

Kermack KA, Musset F And Rigney HW. 1981. The skull of Morganucodon. Zool J Linn Soc Lond 71: $1-158$.

KIELAN-JAWOROWSKA Z. 1971. Skull structures and affinities of the Multituberculata. Palaeont Polonica 25: 5-41.

Kielan-Jaworowska Z, Cifelli RL and LuO ZX. 2004. Mammals from the age of dinosaurs; origins, evolution and structure. Columbia University Press. New York, $630 \mathrm{p}$.

Kischlat EE AND LuCAS SG. 2003. A phytosaur from the Upper Triassic of Brazil. J Vert Paleont 23: 464-467.

KÜHNE WG. 1956. The Liassic Therapsid Oligokyphus. Trustees of the British Museum (Natural History), London, $149 \mathrm{p}$.

LANGER MC, ESCURRA MD, BITTENCOUT JS AND NoVAS F. 2009. The origin and early evolution of dinosaurs. Biological Reviews 85: 55-110.

LANGER MC, Ribeiro AM, SCHULTZ CL AND FERIGOLO J. 2007. The continental tetrapod-bering Triassic of South Brazil. New Mexico Museum of Natural History and Science Bulletin 41: 201-218.

Leal LA, Azevedo SK, Kellner AW And DA RosA AS. 2003. A new early dinosaur (Sauropodomorpha) from the Caturrita Formation (Late Triassic), Paraná Basin, Brazil. Zootaxa 690: 1-24.
LillegraVEn JA AND KRUSAT G. 1991. Craniomandibular anatomy of Haldanodon exspectatus (Docodontia; Mammalia) from the Late Jurassic of Portugal and its implications to the evolution of mammalian characters. Contrib Geol, Univ Wyoming 28: 39-138.

LiU J AND OLSEN P. 2010. The phylogenetic relationships of Eucynodontia (Amniota: Synapsida). J Mammal Evol 17: 151-176.

LuCAS SG AND LuO Z-X. 1993. Adelobasileus from the Upper Triassic of western Texas: the oldest mammal. J Vert Paleont 13: 309-334.

LUO Z-X. 1994. Sister-group relationships of mammals and transformation of diagnostic mammalian characters. In: Fraser NC AND SuEs HD (Eds), In the shadow of the dinosaurs, Cambridge University Press, Cambridge, p. $98-128$.

LUO Z-X. 2007. Transformation and diversification in the early mammalian evolution. Nature 450: 1011-1019.

LuO Z-X AND CROMPTON AW. 1994. Transformation of the quadrate (incus) through the transition from non-mammalian cynodonts to mammals. J Vert Paleont 14: 341374.

LuO Z-X, CROMPTON AW AND LUCAS SG. 1995. Evolutionary origins of the mammalian promontorium and cochlea. J Vert Paleont 15: 113-121.

Luo Z-X, Crompton AW And Sun A-L. 2001. A new mammaliaform from the Early Jurassic of China and evolution of mammalian characteristics. Science 292: 15351540 .

Luo Z-X, Kielan-JaworowsKa Z AND CifElli R. 2002. In quest for a phylogeny of Mesozoic mammals. Acta Palaeontol Polonica 47(1): 1-78.

Maier W, van Der HeEver J And Durand F. 1996. New therapsid specimens and the origin of the secondary hard and soft palate of mammals. J Zoo Syst Research 34: 9-19.

Martinelli A, Bonaparte JF, Schultz CL And RUBERT R. 2005. A new tritheledontid from the Late Triassic of Brazil and its phylogenetic relationships among carnivorous non-mammalian eucynodonts. Ameghiniana 42: 191-208.

Martinelli AG and Rougier GW. 2007. On Chaliminia musteloides (Eucynodontia: Tritheledontidae) from the Late Triassic of Argentina, and a phylogeny of Ictidosauria. J Vert Paleont 27(2): 442-460.

Martinez RM, Sereno P, Alcober O, Colombi C, Renne P, Montañez I AND Currie B. 2011. A basal dinosaur from the Dawn of the Dinosaur Era in Southwestern Pangea. Science 331: 206-210. 
Oliveira TV, Martinelli AG And SoAres MB. 2010. New material of Irajatherium hernandezi Martinelli, Bonaparte, Schultz and Rubert 2005 (Eucynodontia, Tritheledontidae) from the Upper Triassic (Caturrita Formation, Paraná Basin) of Brazil. Paläont Zeitschrift DOI:10.1007/s12542-010-0078-5

OWEN R. 1961. Palaeontology, or a Systematic Summary of Extinct Animals and their Geological Relationships, second edition. Edinburgh: Adam and Black, 463 p.

Rodrigues PG, Schultz CL And SoAres MB. 2006. A comparative study of the cranial cavities of South American cynodonts from Triassic through CT Scan: physiological and evolutionary implications. In: XXII JORNADAS Argentinas de Paleontología de Vertebrados. Libro de resúmenes, San Juan, Argentina, 33 p.

Rogers RR, Swisher CC, Sereno P, Moneta AM, Foster CA AND MARTínez RN. 1993. The Ischigualasto Tetrapod assemblage (Late Triassic, Argentina) and K/40 Ar/39 dating of dinosaur origins. Science 260: 794 797.

ROMER AS. 1969. The Brazilian cynodont reptiles Belesodon and Chiniquodon. Breviora 332: 1-16.

Romer AS. 1970. The Chañares (Argentina) Triassic reptile fauna. VI. A chiniquodontid cynodont with an incipient squamosal-dentary jaw articulation. Breviora 344: 1-18.

Rougier G, Wible J And Hopson J. 1992. Reconstruction of the cranial vessels in the early cretaceous mammal Vincelestes neuquenianus: implications for the evolution of the mammalian cranial vascular system. J Vert Paleont 12(2): 188-216.

Rowe T. 1988. Definition, diagnosis and the origin of mammalia. J Vert Paleont 8: 241-264.

Rowe T. 1993. Phylogenetic systematics and the early history of mammals. In: SzALAY FS ET AL. (Eds), Mammal phylogeny: Mesozoic Differentiation, Multituberculates, Monotremes, Early Therians, and Marsupials, Springer Verlag, New York, p. 129-145.

RUBERT R AND SCHULTZ CL. 2004. Um novo horizonte de correlação para o Triássico Superior do Rio Grande do Sul. Pesquisas em Geociências 31: 71-88.

SCHERER CMS, FACCINI UF AND LAVINA EL. 2000. Arcabouço estratigráfico do Mesozóico da Bacia do Paraná. In: Holz M AND DE Ros LF (Eds), Geologia do Rio Grande do Sul, CIGO/UFRGS, Porto Alegre, p. 335-354.
SCHUltz CL, SCHERER CSM AND BARBERENA MC. 2000. Biostratigraphy of southern Brazilian Middle-Upper Triassic. Rev Bras Geocien 30(3): 495-498.

Schultz CL And SoAres MB. 2006. Proposta de nova denominação para a Cenozona de Ictidosauria do Triássico Superior (Formação Caturrita) do Rio Grande do Sul. In: Simpósio Brasileiro de Paleontologia de VerTEBrados, 5. Ciência \& Natura, Santa Maria, UFSM, $41 \mathrm{p}$.

Sidor CA AND HANCOX PJ. 2006. Elliotherium kersteni, a new tritheledontid from the Lower Elliot Formation (Upper Triassic) of South Africa. J Paleont 80(2): 333-342.

SuES HD. 1986. The skull and dentition of two tritylodontid synapsids from the lower Jurassic of western North America. Bull Mus Comp Zool 151: 217-268.

SUN A-L. 1984. Skull morphology of the tritylodont genus Bienotheroides of Sichuan. Scientia Sinica B27: 270 284.

TEIXEIRA AM. 1982. Um novo cinodonte carnívoro (Probelesodon kitchingi sp. nov.) do Triássico do Rio Grande do Sul, Brasil. Comun Mus Cienc PUCRS 24: 1-31.

WATSON DMS. 1921. The bases of the classification of Theriodonta. Proc Zool Soc Lond, p. 35-98.

WIBLE JR. 1991. Origin of Mammalia: the craniodental evidence reexamined. J Vert Paleont 11: 1-28.

WIBLE JR AND Hopson JA. 1993. Basicranial evidence for early mammal phylogeny. In: SzALAY FS ET AL. (Eds), Mammal Phylogeny. Mesozoic differentiation, Multituberculates, Monotremes, Early Therians, and Marsupials, Springer-Verlag, p. 45-62.

Wible JR, Novacek MJ And Rougier GW. 2004. New data on the skull and dentition of the Mongolian Cretaceous eutherian mammal Zalambdalestes. Bull Amer Mus Nat Hist 281: 1-144.

YounG CC. 1947. Mammal-like reptiles from Lufeng, Yunnan, China. Proc Geol Soc London 117: 537-597.

Zerfass H, Lavina EL, Schultz CL, Garcia AJV, FACCini UF AND Chemale JR F. 2003. Sequence stratigraphy of continental Triassic strata of Southernmost Brazil: a contribution to Southwestern Gondwana palaeogeography and palaeoclimate. Sedimentary Geol 161: 85-105. 